Universidade Federal de Santa Catarina Departamento de História Campus Universitário UFSC - CFH 88040-970 - Florianópolis - SC kramerhis@gmail.com

\section{ROÇAS, FAZENDAS, ENGENHOS, CURRAIS: UMA CARTOGRAFIA DA RURALIDADE COLONIAL NAS MINAS DO CUIABÁ (PRIMEIRA METADE DO SÉCULO XVIII)*}

\author{
Tiago Kramer de Oliveira* \\ Universidade Federal de Santa Catarina \\ Florianópolis - Santa Catarina - Brasil
}

\title{
Resumo
}

Neste artigo analisamos a formação de ambientes rurais nas Minas do Cuiabá na primeira metade do século XVIII. Utilizamos relatos, crônicas, correspondências oficiais, cartas de sesmarias e documentação cartográfica para reconstruirmos detalhes da espacialização da ruralidade no centro da América do Sul. Acreditamos que um estudo detalhado pode servir para problematizarmos estudos que em outras escalas procuraram caracterizar a formação do meio rural no contexto da expansão das conquistas portuguesas no século XVIII.

\section{Palavras-chave}

História agrária do Brasil colonial - economia colonial - Minas do Cuiabá.

* Pesquisa realizada com apoio da Capes.

** Doutor em História pelo Programa de Pós-Graduação em História Econômica da Faculdade de Filosofia, Letras e Ciências Humanas da Universidade de São Paulo e professor do Departamento de História, do Centro de Filosofia e Ciências Humanas. 


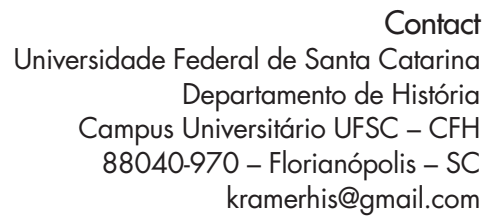

Contact

Universidade Federal de Santa Catarina Departamento de História Campus Universitário UFSC - CFH 88040-970 - Florianópolis - SC kramerhis@gmail.com

\section{ROÇAS, FAZENDAS,}

ENGENHOS, CURRAIS:

A CARTOGRAPHY OF COLONIAL RURALITY IN

THE MINES OF CUIABÁ

(EARLY EIGHTEENTH CENTURY)

\section{Tiago Kramer de Oliveira}

Universidade Federal de Santa Catarina

Florianópolis - Santa Catarina - Brazil

\begin{abstract}
In this article we analyzed the formation of rural environments in the Minas do Cuiabá, in the first half of the eighteenth century. We use reports, essays, official correspondence, letters of "sesmarias" and cartographic documentation to reconstruct details of the spatialization of rurality in center of South America. We believe that a detailed study can serve to problematize studies that in other scales sought to characterize the formation of the rurality in the context of the expansion of the Portuguese conquests in the eighteenth century.
\end{abstract}

\title{
Keywords
}

Agrarian history of colonial Brazil - colonial economy - Minas do Cuiabá 
rev. hist. (São Paulo), n. 173, p. 211-251, jul.-dez., 2015 http://dx.doi.org/10.11606/issn.2316-9141.rh.2015.98800
Tiago Kramer de Oliveira

Roças, fazendas, engenhos, currais: uma cartografia da ruralidade colonial nas Minas do Cuiabá (primeira metade do século XVIII)

Nas últimas décadas, têm se fortalecido entre os historiadores perspectivas de construção do conhecimento histórico que valorizam os estudos que investigam em detalhes temas e objetos que, muitas vezes, eram circunscritos a discursos generalizadores. Com felicidade, Jacques Revel fez analogia dessas perspectivas com a cartografia. Mais do que apenas investigar aspectos não revelados em mapas em escala maior, os historiadores têm "jogado com as escalas" estabelecendo uma relação de ressignificação entre o específico e o geral. ${ }^{1}$

Neste artigo, construímos nossa análise com foco nas particularidades, procurando "ver de perto" a formação de ambientes rurais nos primeiros anos de colonização portuguesa nos territórios que formavam a região das Minas do Cuiabá, no centro da América do Sul. Acreditamos que as minudências que destacaremos podem servir para ressignificar "mapas" que, em outras escalas, representaram o lugar dessas espacializações² na economia colonial.

Autores como Caio Prado Júnior, Celso Furtado, Sérgio Buarque de Holanda, Nelson Werneck Sodré, entre outros, construíam imagens da ruralidade colonial dessa região, marcadas pelo improviso, inconstância, irra-

\footnotetext{
REVEL, Jacques. Microanálise e a construção do social. In: REVEL, Jacques. Jogos de escalas: a experiência da microanálise. Tradução de Dora Rocha. Rio de Janeiro: EFGV, 1998, p. 20.

2 Seguimos Milton Santos, para quem "a espacialidade seria um momento das relações sociais geografizadas, o momento da incidência da sociedade sobre um determinado arranjo espacial". SANTOS, Milton. Metamorfoses do espaço habitado: fundamentos teórico e metodológico da geografia. São Paulo: Hucitec, 1988, p. 26. Quanto às noções de territorialização, desterritorialização e reterritorialização que empregaremos ao longo do artigo, além de recorrermos a Milton Santos, fomos "afetados" pelas argutas e inspiradoras reflexões de Gille Deleuze e Félix Guattari, levando em conta (sem necessariamente estar de pleno acordo) as ponderações e críticas de Rogério Haesbaert. DELEUZE, Gille E G GUATTARI, Félix. Mil platôs - capitalismo e esquizofrenia, v 1. Tradução de Ana Lúcia de Oliveira. Rio de Janeiro: Ed. 34, 1995, p. 24. SANTOS, Milton. A natureza do espaço: técnica, razão e emoção. São Paulo: Edusp, 2006, p. 124; HAESBAERT, Rogério. O mito da desterritorialização: do "fim dos territórios" à multiterritorialidade. Rio de Janeiro: Bertrand Brasil, 2006; HAESBAERT, Rogério \& BRUCE, Glauco. A desterritorialização em Deleuze e Guattari. GEOgraphia, ano 6, n 7, 2002, p. 07-31; HAESBAERT, Rogério \& RAMOS, Tatiana T. O mito da desterritorialização econômica. GEOgraphia, ano 6, n 12, 2004, p. 25-48, p. 29; 45-46. No contexto que a tratamos, entendemos a espacialização como um processo de desterritorialização de sociedades indígenas e de territorialização de ambientes coloniais. Entretanto, o binômio territorialização/desterritorialização é insuficiente para tal entendimento, uma vez que consiste em um duelo de forças a priori antagônicas e anteriores à ação sobre o espaço. Tanto as práticas colonizadoras quanto as práticas ameríndias concretizam-se no território apenas na relação que mantêm entre si dando origem a uma série de arranjos espaciais, as reterritorializações. O uso do termo espacialização (e os verbos derivados), portanto, subentende e procura explicitar a densidade da dimensão espacial das conquistas.
} 
rev. hist. (São Paulo), n. 173, p. 211-251, jul.-dez., 2015 http://dx.doi.org/10.11606/issn.2316-9141.rh.2015.98800
Tiago Kramer de Oliveira

Roças, fazendas, engenhos, currais: uma cartografia da ruralidade colonial nas Minas do Cuiabá (primeira metade do século XVIII)

cionalidade, descaso, irregularidade, escassez e isolamento, ${ }^{3}$ imagens que se estenderam, ainda, aos ambientes urbanos. Estudos de referência para a historiografia regional como os de Virgílio Corrêa Filho e Luíza R. R. Volpato relacionaram a formação de ambientes rurais à crise do setor minerador. Para Virgílio Corrêa Filho "à medida que esmoreciam as minas de ouro, pelo esgotamento dos aluviões empiricamente lavrados, maiores esforços desviados da mineração evanescente iriam aplicar-se na lavoura e criação de gado". ${ }^{4}$ Extremando a percepção de Corrêa Filho, Luíza Volpato caracterizou o meio rural como espaço de subsistência e de pobreza (ou mesmo miséria) formado em decorrência de uma profunda crise na produção aurífera. ${ }^{5}$

Os estudos históricos sobre as conquistas portuguesas no centro da América do Sul têm, nas últimas décadas, construído interpretações que rompem com as "imagens" expostas no parágrafo anterior. Ainda na década de 1980, a dissertação de mestrado de Elmar Arruda, inspirada nos estudos de Ciro Flamarion Cardoso, ${ }^{6}$ defendeu que desde o princípio das atividades de mineração formou-se um mercado interno que consistia em uma "estru-

\footnotetext{
3 Caio Prado caracteriza a agricultura em áreas de mineração como atividade de "subsistência" praticada por livres pobres e afirma que "a mediocridade desta mesquinha agricultura de subsistência que praticam, e que nas condições econômicas da colônia não podia ter senão este papel secundário e de nível extremamente baixo, leva para elas, por uma espontânea seleção social, econômica e moral, as categoria inferiores da colonização". PRADO JÚNIOR, Caio. Formação do Brasil contemporâneo - Colônia. São Paulo: Brasiliense, 1997, p. 161. Celso Furtado aponta para "a quase inexistência de abastecimento local de alimentos" no Mato Grosso colonial. FURTADO, Celso. Formação econômica do Brasil. 32 $2^{\mathrm{a}}$ edição. São Paulo: Companhia Editora Nacional, 2003, p. 83. Para Sérgio Buarque de Holanda "os benefícios mais seguros, embora também mais trabalhosos da lavoura foram logo abandonados pelos do reluzente metal das minas"; ele afirma que "os primeiros moradores do arraial cuiabano tiveram uma existência comparável à dos índios coletores e caçadores, existência que só se concilia com um modo de vida andejo e inconstante". HOLANDA, Sérgio Buarque. Caminhos e fronteiras. São Paulo: Cia das Letras, 1994, p. 138; 149. A respeito da colonização de Cuiabá, Sodré afirma: "estava fixada a cidade. Sua população aumentava sem cessar. Tudo contra eles lutava, entretanto. Os alimentos andavam escassos. Só se cuidava da mineração". SODRE, Nelson Werneck. Oeste. Ensaio sobre a grande propriedade pastoril. São Paulo: Arquivo do Estado, 1990, p. 45; 67.

${ }^{4}$ CORRÊA FILHO, Virgílio. Pantanais matogrossenses. Devassamento e ocupação. IBGE: Rio de Janeiro, 1946, p. 112.

5 VOLPATO, Luiza Rios Ricci. A conquista da terra no universo da pobreza: formação da fronteira oeste do Brasil. São Paulo: Hucitec, 1987, p. 19; 99-100.

${ }^{6}$ CARDOSO, Ciro Flamarion S. A brecha camponesa no sistema escravista. In: CARDOSO, Ciro Flamarion S. Agricultura, escravidão e capitalismo. Petrópolis: Vozes, 1979, p. 133-154. CARDOSO, Ciro Flamarion S. As concepções acerca do "sistema econômico mundial" e do "antigo sistema colonial": a preocupação obsessiva com a "extração de excedente". In: AMARAL LAPA, J. R. do (org.). Modos de produção e realidade brasileira. Petrópolis: Vozes, 1980, p. 109-132.
} 
tura" que funcionou como "suporte de sustentação econômica", uma vez que "produzir para a exportação continua sendo a baliza do sistema, mas não consegue abarcar o sentido da economia".7 Já na década de 1990, há diversos estudos, fundamentalmente teses de doutorado, que redimensionaram a historiografia sobre o Mato Grosso colonial.

Jovam Vilela da Silva, em "A capitania de Mato Grosso: povoamento e população, século XVIII", desenvolveu um estudo sobre as estratégias das autoridades portuguesas para efetivar a conquista dos territórios em litígio com a Coroa de Castela. Segundo Vilela, o desenvolvimento de atividades agrícolas, pastoris e de extrativismo era uma preocupação constante das autoridades portuguesas. $\mathrm{O}$ autor defendeu a existência de um espaço entre objetivos mercantilistas da Coroa portuguesa e o escravismo para o desenvolvimento de atividades agrícolas, pastoris e de extrativismo vegetal e animal, e como a formação do meio rural estava articulada com a política de abastecimento e da ampliação das fronteiras coloniais. ${ }^{8}$

A tese de Carlos Alberto Rosa, Vila Real do Senhor Bom Jesus do Cuiabá. Vida urbana em Mato Grosso no século XVIII: 1722-1808, embora tenha tratado especialmente do meio urbano, abordou várias questões pertinentes à formação de ambientes rurais, particularmente na relação entre o exercício de poder nos ambientes urbanos e a espacialização de atividades rurais. $\mathrm{O}$ autor reforçou a percepção de Elmar F. Arruda quanto à concomitância entre produção aurífera e produção agrícola e criatória. No entanto, absorveu tal percepção a partir da estrutura do antigo sistema colonial ${ }^{9}$ que, ao impulsionar a exploração, dava espaço para a territorialização de ambientes urbanos e rurais o que, em essência, contradizia a lógica meramente exploratória da colonização, mas que, do ponto de vista "sistêmico", integrava-a como contradição necessária para o funcionamento de suas engrenagens. ${ }^{10}$

Mesmo que não abordem a "questão agrária", há vários outros estudos de referência que não temos espaço para discutir, mas que aprofundaram o

\footnotetext{
7 ARRUDA, Elmar Figueiredo. O mercado interno de Mato Grosso - século XVIII. Dissertação de mestrado em História, PUC, 1987, p. 48.

8 SILVA, Jovam Vilela da. Mistura de cores. Política de povoamento e população na capitania de Mato Grosso - século XVIII. Cuiabá: UFTM, 1995.

9 NOVAIS, Fernando A. Portugal e Brasil na crise do antigo sistema colonial (1777-1808). São Paulo: Hucitec, 1986.

${ }^{10}$ ROSA, Carlos Alberto. A Vila Real do Senhor Bom Jesus do Cuiabá. Vida urbana em Mato Grosso no século XVIII (1727-1808). Tese de doutorado em História, FFLCH, USP, 1996.
} 
rev. hist. (São Paulo), n. 173, p. 211-251, jul.-dez., 2015 http://dx.doi.org/10.11606/issn.2316-9141.rh.2015.98800
Tiago Kramer de Oliveira

Roças, fazendas, engenhos, currais: uma cartografia da ruralidade colonial nas Minas do Cuiabá (primeira metade do século XVIII)

conhecimento sobre diversos aspectos da colonização de Mato Grosso. ${ }^{11}$ Nos anos 2000, várias dissertações de mestrado foram produzidas sobre Mato Grosso colonial, entre elas estudos que tratavam da história agrária. Foi neste contexto que desenvolvemos nosso primeiro estudo sobre o tema. ${ }^{12} \mathrm{O}$ estudo de Masília A. Gomes sobre as práticas alimentares apontou a relação entre essas práticas e uma relativamente diversificada produção local. ${ }^{13}$ Já a pesquisa de Vanda da Silva procurou desvendar a concessão de terras por cartas de sesmarias como "espaço de negociação", levando em conta principalmente os interesses da elite local na segunda metade do século XVIII. ${ }^{14}$

Embora o objetivo do artigo não seja desenvolver uma extensa discussão bibliográfica sobre o tema, destacamos que os estudos que têm como recorte espacial a região da capitania de Minas Gerais são particularmente significativos para nossa pesquisa. Sobre o "abastecimento" em áreas de mineração, o estudo desenvolvido ainda na década de 1950 por Mafalda Zemella investiga a formação de ambientes rurais voltados para a alimentação e ainda afirma que, apesar das diversas disposições legais contrárias, houve a edificação de um considerável número de engenhos de cana-de-açúcar nas áreas de exploração aurífera. ${ }^{15}$ Cerca de trinta anos depois, o estudo de Carlos Magno Guimarães e Liana Reis, fundamentado na análise de cartas de sesmarias, concluiu que o trabalho escravo em escala considerável era utilizado na capitania de Minas Gerais desde o início da colonização na região. ${ }^{16}$ Mais re-

${ }^{11}$ COSTA, Maria de Fátima. Notícias de Xarayes. Pantanal entre os séculos XVI e XVIII. Tese de doutorado em História, FFLCH, USP, 1997. CANAVARROS, Otávio. O poder metropolitano em Cuiabá (1727-1748). Cuiabá: Ed. da UFMT, 2004. ANZAI, Leny C. Doenças e práticas de cura na capitania de Mato Grosso: o olhar de Alexandre Rodrigues Ferreira. Tese de doutorado em História, UNB, 2004. JESUS, Nauk Maria de. Na trama dos conflitos: a administração na fronteira oeste da América portuguesa (1719-1778). Tese de doutorado em História, ICHF, UFF, 2006.

12 OLIVEIRA, Tiago Kramer de. Ruralidade na terra da conquista: Ambientes rurais luso-americanos no centro da América do Sul (1716-1750). Dissertação de mestrado, UFMT, 2008.

${ }^{13}$ GOMES, Masília A. da S. Os "gêneros do país": a produção de alimentos em Vila Bela da Santíssima Trindade (1748-1790). In: ANZAI, Leny C. \& MARTINS, Maria Cristina B. Histórias coloniais em áreas de fronteira: índios, jesuítas e colonos. São Leopoldo, RS: Oikos; Unisinos; Cuiabá, MT: EduFMT, 2008.

${ }^{14}$ SILVA, Vanda da. Administração das terras: a concessão de sesmarias na capitania de Mato Grosso (17481823). Dissertação de mestrado em História, ICHS, UFMT, 2008. Mais recentemente, Divino M. Sena estudou a presença de livres pobres em ambientes rurais já no final do período colonial. SENA, Divino Marcos de. Camaradas: livres e pobres em Mato Grosso (1808-1850). Dissertação de mestrado em História, UFGD, 2010.

${ }^{15}$ ZEMELLA, Mafalda P. O abastecimento da capitania das Minas Gerais no século XVIII. São Paulo: Ed. Hucitec-Edusp, 1990.

${ }^{16}$ GUIMARÃES, Carlos Magno \& REIS, Liana M. Agricultura e escravidão em Minas Gerais (1700/1750). Revista do Departamento de História da UFMG, 1986. 
rev. hist. (São Paulo), n. 173, p. 211-251, jul.-dez., 2015 http://dx.doi.org/10.11606/issn.2316-9141.rh.2015.98800
Tiago Kramer de Oliveira

Roças, fazendas, engenhos, currais: uma cartografia da ruralidade colonial nas Minas do Cuiabá (primeira metade do século XVIII)

centemente, pesquisadores têm aprofundado os estudos sobre o agrário nos "primeiros tempos" da colonização. José Newton C. Meneses optou pela caracterização social da produção alimentar, enquanto Angelo A. Carrara investigou a produção rural local no âmbito da história econômica. Em comum, os autores partilham em suas análises de perspectivas que caracterizam a produção alimentar como expressão da dinâmica interna da economia mineira. ${ }^{17}$

No âmbito dos estudos históricos sobre o agrário colonial, são basilares os trabalhos de Maria Yedda Linhares e de Francisco Carlos Teixeira da Silva. As pesquisas desenvolvidas pelos autores, além de inúmeras dissertações e teses produzidas no grupo de pesquisadores liderados por Linhares, consolidaram uma orientação de pesquisa que caracteriza a produção de alimentos e a disponibilidade de terras como dois dos três elementos fundamentais para a manutenção da agricultura extensiva voltada para a exportação. ${ }^{18}$ No entanto, a produção voltada para o mercado interno não era vista meramente como um setor dependente do setor exportador. A proeminência do setor exportador, no argumento de Francisco C. Teixeira da Silva, não era garantida por uma lógica mercantil externa, mas, sobretudo, por políticas coloniais que privilegiaram o grupo social detentor das grandes lavouras exportadoras em detrimento dos segmentos sociais que produziam para o mercado interno (tanto segmentos intermediários, compostos por criadores de gado, quanto de livres pobres plantadores de alimentos). ${ }^{19}$

\footnotetext{
${ }^{17}$ MENESES, José Newton Coelho. O continente rústico: abastecimento alimentar nas Minas Gerais setecentistas. Diamantina: Maria Fumaça, 2000. CARRARA, Angelo Alves. Ocupação territorial e estrutura fundiária: as minas e os currais (1674-1850). Estudos de História. Franca, v. 08, n. 2, 2001, p. 81-97. CARRARA, Angelo Alves. Minas e currais: produção rural e mercado em Minas Gerais 1674-1807. Juiz de Fora: Ed. UFJF, 2007.

${ }^{18}$ Linhares sintetiza a trajetória das pesquisas desenvolvidas entre 1977 e 1995, no âmbito Programa de História da Agricultura Brasileira: "com mais de trinta pesquisas concluídas e a publicação de numerosos artigos e livros, além de teses extremamente substanciais, construímos uma hipótese central segundo a qual a economia aqui engendrada nos primeiros séculos, baseada na agricultura extensiva, tinha sua reprodução dependente da presença de três elementos cuja oferta deveria ser elástica, isto é, terras, homens e alimentos. À existência em algumas regiões da fronteira agrícola aberta, apesar da persistente resistência das populações indígenas, combinavam-se o tráfico atlântico, inesgotável supridor de escravos africanos, e a produção de alimentos em escala crescente". LINHARES, Maria Yeda. Pecuária, alimentos e sistemas agrários no Brasil (séculos XVII e XVIII). Tempo, v. 1, n. 2, 1996, p. 132-150, p. 134. LINHARES, Maria Y. Subsistência e sistemas agrários na colônia, uma discussão. Estudos Econômicos, USP, vol. 13, número especial, 1983, p. 745 -762; LINHARES, Maria Yedda \& TEIXEIRA DA SILVA, Francisco Carlos. História da agricultura brasileira, combates e controvérsias. São Paulo: Brasiliense, 1981.

${ }^{19}$ TEIXEIRA DA SILVA, Francisco Carlos. Pecuária e formação do mercado interno no Brasilcolônia. Estudos Sociedade e Agricultura, 1997, p. 119-156.
} 
rev. hist. (São Paulo), n. 173, p. 211-251, jul.-dez., 2015 http://dx.doi.org/10.11606/issn.2316-9141.rh.2015.98800
Tiago Kramer de Oliveira

Roças, fazendas, engenhos, currais: uma cartografia da ruralidade colonial nas Minas do Cuiabá (primeira metade do século XVIII)

Nos estudos mais recentes de Marcia Motta sobre a história agrária colonial - cujo foco descola-se do "abastecimento" para a problematização das relações de poder que engendram a posse da terra - a autora faz uma análise da documentação de sesmarias, explorando aspectos dessa documentação não redutíveis às análises quantitativas e de localização geográfica. ${ }^{20}$

Uma vez apresentado, de modo bastante sumário, o estado da questão, esperamos poder acrescentar elementos ao debate, por meio de uma investigação sobre a formação da ruralidade colonial nas Minas do Cuiabá nos primeiros anos da colonização portuguesa na região e, para tanto, recorremos a uma diversidade de tipologias documentais: cartas de sesmarias, relatos de exploradores, correspondências oficiais e documentação cartográfica.

Embora o topônimo Minas pareça denotar apenas explorações auríferas, a área que na documentação aparece circunscrita às Minas do Cuiabá e posteriormente ao termo - para utilizarmos uma expressão da época - da Vila Real do Senhor Bom Jesus do Cuiabá é muito mais ampla do que as imediações das áreas de exploração de ouro. Os territórios à margem oeste do rio Paraná faziam parte do termo da Vila Real do Senhor Bom Jesus do Cuiabá. Na região entre a barra do rio Pardo e o curso do rio Taquari (figura I) formaram-se ambientes rurais em locais que se tornaram vias de acesso regulares às novas conquistas.

Nos mapas coevos, particularmente naqueles classificados por Jaime Cortesão como "sertanistas", ${ }^{21}$ podemos perceber a representação de uma ampla rede urbana. Por outro lado, não há muitos indícios nesses mapas sobre a formação de ambientes rurais no imenso território habitado por inúmeros povos ameríndios e que, em poucos anos, nas primeiras décadas

\footnotetext{
${ }^{20}$ MOTTA, Marcia M. Menendes. Direito a terra no Brasil: a gestação do conflito, 1795-1824. São Paulo: Alameda, 2009. MOTTA, Márcia Maria M. Francisco Maurício de Souza Coutinho: sesmarias e os limites do poder. In: VAINFAS, Ronaldo; SANTOS, Georgina Silva dos; NEVES, Guilherme Pereira (org.). Retratos do Império: trajetórias individuais no mundo português nos séculos XVI ao XIX. Niterói: EdUFF, 2006, p. 259-277. MOTTA, Márcia Maria M. Poder e domínio: a concessão de sesmarias em fins de Setecentos. In: MONTEIRO, Rodrigo B. \& VAINFAS, Ronaldo. Império de várias faces: relações de poder no mundo ibérico da Época Moderna. São Paulo: Alameda, 2009. MOTTA, Márcia Maria M. Nas fronteiras do poder: conflito de terra e direito a terra no Brasil do século XIX. Rio de Janeiro: Vício de Leitura; Aperj, 1998. Ao longo do texto faremos as devidas referências às contribuições da autora ao presente estudo.

${ }^{21}$ CORTESÃO, Jaime. História do Brasil nos velhos mapas, tomo II. Lisboa: Imprensa Nacional; Casa da Moeda, 2009, p. 231. Analisamos de forma mais detida a documentação cartográfica classificada por Jaime Cortesão como "sertanista". OLIVEIRA, Tiago Kramer de. Cartografias do "sertão": os mapas sertanistas nos discursos históricos de Jaime Cortesão e Sérgio Buarque de Holanda. Territórios \& Fronteiras, v. 6, n. 2, 2013, p. 188-210.
} 
rev. hist. (São Paulo), n. 173, p. 211-251, jul.-dez., 2015 http://dx.doi.org/10.11606/issn.2316-9141.rh.2015.98800
Tiago Kramer de Oliveira

Roças, fazendas, engenhos, currais: uma cartografia da ruralidade colonial nas Minas do Cuiabá (primeira metade do século XVIII)

do século XVIII, foi incorporado aos domínios portugueses na América. Há ao menos um mapa, contudo, que faz referência às roças próximas ao rio Pardo. Trata-se da carta Parte do gouerno de Sam Paulo e parte dos dominios da Coroa de Espanha, datada de 1740 (figura II). ${ }^{22}$

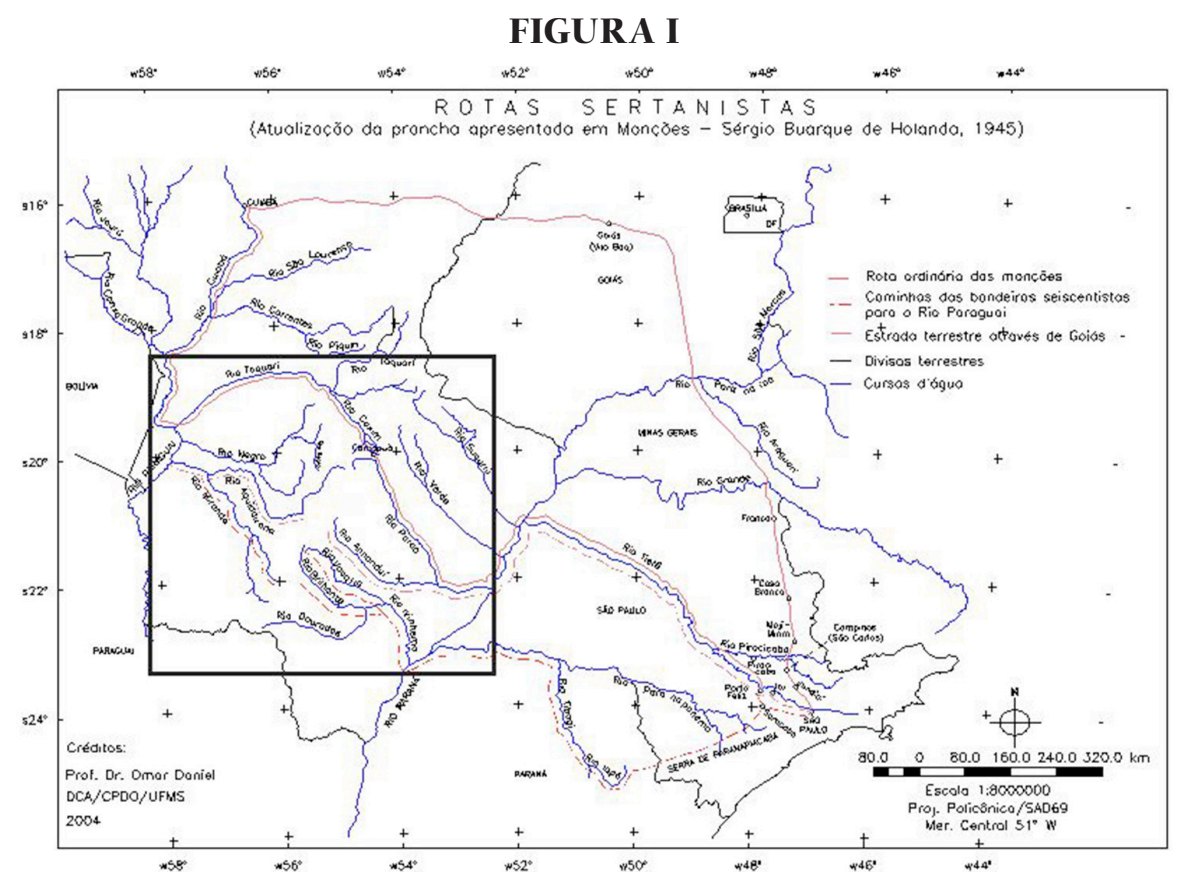

DANIEL, Omar. Mapa das rotas das monções e das bandeiras seiscentistas, atualizada por georreferenciamento, a partir da prancha de Sérgio Buarque de Holanda, em 1945, apud BRASIL, Maria do Carmo \& DANIEL, Omar. Sobre a rota das monções. Navegação fluvial e sociedade sob o olhar de Sérgio Buarque de Holanda. RIHGB, Rio de Janeiro, v. 169, 1998, nº 438.

\footnotetext{
${ }^{22} \mathrm{O}$ mapa foi produzido no contexto das disputas entre Portugal e Espanha pelos territórios fronteiriços no centro da América do Sul, contexto no qual a Coroa portuguesa procurava ter informações cada vez mais precisas sobre o território em disputa. Sobre o autor do mapa, não temos nenhuma indicação de quem possa tê-lo produzido. Contudo, os indícios nos levam a crer que os mapas teriam sido feitos com base nos relatos dos exploradores e autoridades, pois as informações espacializadas correspondem àquelas dos relatos. Obviamente que, assim como as outras tipologias documentais, os mapas não oferecem uma representação precisa e objetiva dos espaços e qualquer problematização feita a partir da análise desse tipo de documento deve levar em conta seus limites. Utilizamo-lo como uma fonte de indícios sobre a espacialização da ruralidade, que precisa ser entrecruzado com outros documentos, com o objetivo de oferecer uma interpretação sobre a formação de ambientes rurais. Sobre a metodologia de crítica documental dos mapas, ver OLIVEIRA, Tiago Kramer de. Desconstruindo mapas, revelando espacializações: reflexões sobre o uso da cartografia em estudos sobre o Brasil colonial. Revista Brasileira de História, n. 68, 2014, p. 151-174.
} 


\section{FIGURA II}

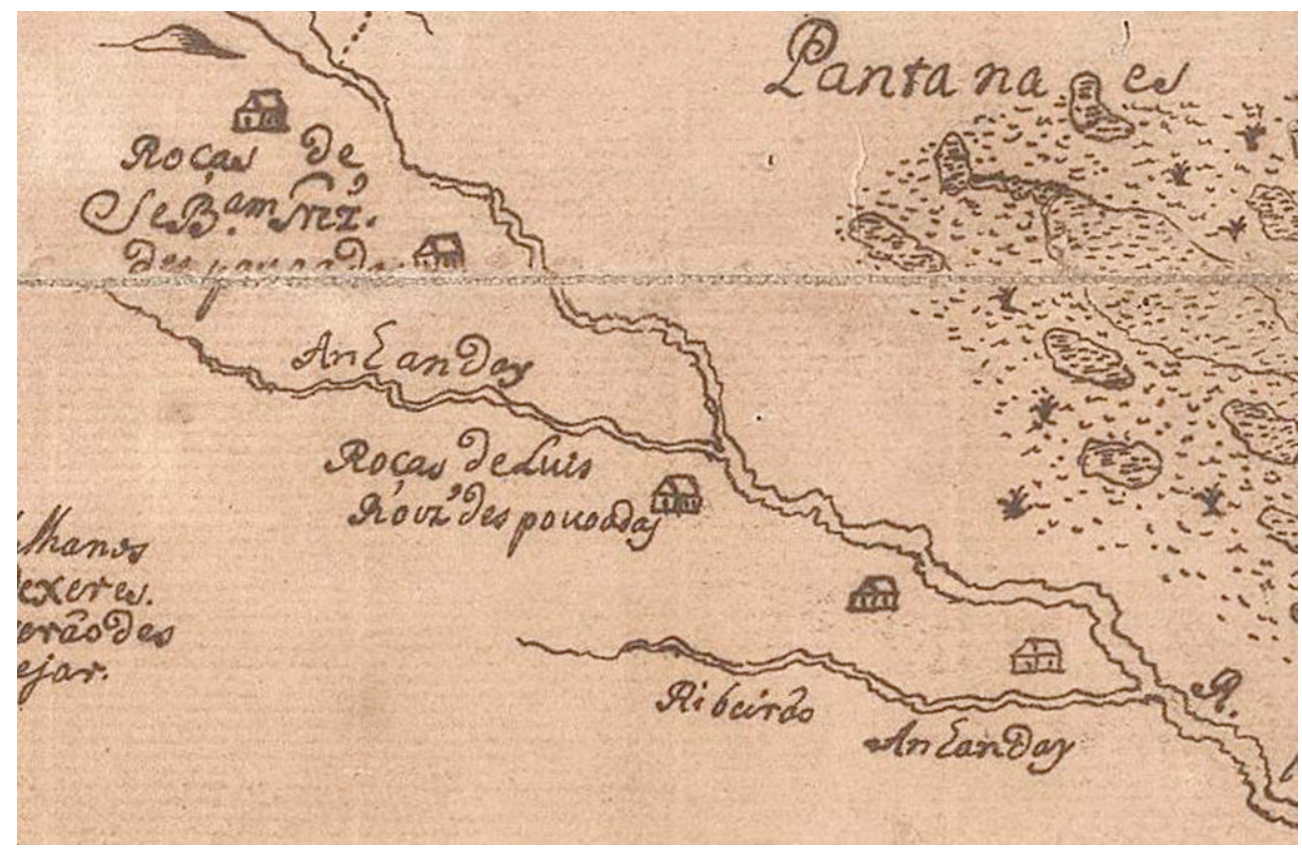

Detalhe do Parte do gouerno de Sam Paulo e parte dos dominios da Coroa de Espanha, ca 1740, 51,5 x 71cm. Biblioteca Nacional (Brasil), Coleção Bibliotheca Nacional Publica da Corte.

Na margem esquerda do rio Pardo, é representada a presença de ambientes rurais com a figura de uma edificação. No curso do rio recortado no mapa, aparecem cinco dessas pequenas casas. Nas proximidades de três delas são discriminados os proprietários das roças. Dos dois proprietários, encontramos na documentação apenas referência a Luís Rodrigues. O relato de Cabral Camelo aponta que,

Por todo este grande rio [Pardo] costumam andar os Cayapós; (...) no pequeno riacho de Camapoam, uma légua pouco mais ou menos de seu nascimento, em sítio em que estão duas roças povoadas, e se gastam nesta paragem quinze ou vinte dias; é porém precisa toda a vigilância nela porque os Cayapós não perdem toda a boa ocasião que se lhes oferece: com o efeito experimentaram uns de São Paulo, que foram na mesma tropa, por nomes Luiz Rodrigues Villares e Gregório de Castro, que no meio da fileira de negros que lhe conduziam as cargas, e seriam sessenta ou mais, lhes ataram três ou quatro (...). Estes dois pobres roceiros vivem como em um presídio, com as armas sempre nas mãos (...) colhem contudo bastante milho e feijão, e o vendem muito bem (...) e as galinhas, porcos e cabras (...). A roça de cima tem já seu canavial e bananal, e está cercada toda de uma boa estacada (...) (grifos nossos) (...). Abaixo das itaipavas há duas roças, que se lançaram no ano em que eu passei aquelas minas; mas como até aqui chegam os Caiapós, não foram de muita dura (...) 
rev. hist. (São Paulo), n. 173, p. 211-251, jul.-dez., 2015 http://dx.doi.org/10.11606/issn.2316-9141.rh.2015.98800
Tiago Kramer de Oliveira

Roças, fazendas, engenhos, currais: uma cartografia da ruralidade colonial nas Minas do Cuiabá (primeira metade do século XVIII)

Este Rio Taquari até o meio tem alguns matos, o mais tudo são campos; dizem que de uma e outra parte há gentios; mas supõe-se que são restos de algumas nações que os sertanistas conquistaram. Destes vi só três bugres, que traziam em sua companhia um Sargento-mor Paulista e eram agigantados. $^{23}$ (grifos nossos)

Outros documentos, como as cartas de sesmarias, mostram que Luiz Rodrigues Villares e Gregório de Castro, com seus mais de sessenta escravos, pareciam não pretender (ou não apenas) aventurar-se em busca de descobertas de ouro. Parece-nos que ambos já tinham outros meios de obtê-lo, de forma líquida e certa.

Luiz Rodrigues Villares, desde ao menos 1722, em sociedade com Antonio Lopes, explorava a criação de gado nos campos de Curitiba, onde requereu e obteve, em 1725, sesmarias de uma légua e meia em quadra. ${ }^{24}$ Já em 1727, o mesmo Luiz Rodrigues requereu ao todo três léguas em quadra em duas sesmarias localizadas justamente no "sítio de Camapuã" e "no Porto Geral do Taquari"25 (figura III).

Lembrando que, de acordo as normas estabelecidas para concessão de sesmarias, a máxima extensão seria de uma légua em quadra para criação de gado e meia légua em quadra para a agricultura, as sesmarias de Camapuã e Taquari extrapolavam em muito a legislação, fato de modo algum incomum no Brasil colonial. ${ }^{26}$

Em uma das sesmarias recebidas por Luiz Rodrigues, ele é descrito como "morador e mercador ${ }^{27}$ na cidade de São Paulo, ora assistente nestas minas do Cuiabá" e "que ele suplicante se achava com posses de fabricar pelo

${ }^{25}$ CAMELO, Antonio Cabral. Notícias práticas das minas do Cuiabá e Goyases na capitania de São Paulo e Cuiabá, que dá ao rev. padre Diogo Soares, o capitão João Antônio Cabral Camelo, sobre a viagem que fez às minas do Cuiabá no ano de 1727. RIHGB, v. 4, n. 13, 1842, p. 487-500, p. 491; 493.

${ }^{24}$ Livro de sesmarias patentes e provisões. Livro 1. Apesp, f. 58.

${ }^{25}$ Livro de sesmarias patentes e provisões. Livro 2. Apesp, f. 137-138.

${ }^{26}$ Como aponta Márcia Motta, “a despeito das tentativas de limitar a expansão e controlá-la via procedimentos régios, havia casos em que o documento de sesmarias servia para assegurar a incorporação de enormes limites territoriais nas mãos de um potentado, em retribuição aos serviços prestados à coroa. Se os pedidos não feriam o que estava escrito em lei, na prática eles ocultavam o assenhoreamento de enormes extensões de terras para uma mesma família. No entanto, mesmo nesses casos, a posição da coroa não foi única. Interesses comuns entre sesmeiros e a coroa poderiam denotar o 'fechar os olhos' para flagrantes usurpações de terra". MOTTA, Márcia Maria M. Poder e domínio: a concessão de sesmarias em fins de Setecentos. In: MONTEIRO, Rodrigo B. E VAINFAS, Ronaldo. Império de várias faces: relações de poder no mundo ibérico da Época Moderna. São Paulo: Alameda, 2009, p. 356.

${ }^{27}$ Lembramos que, na primeira metade do século XVIII, não havia uma normatização para denominação dos agentes mercantis. Apenas em 1770, por força de lei, houve a "codificação do estatuto dos negociantes". PEDREIRA, Jorge Miguel de M. V. Os homens de negócio da praça de Lisboa de Pombal ao Vintismo (1755-1822): diferenciação, reprodução e identificação de um grupo social. Tese de doutorado, Universidade Nova de Lisboa, 1995, p. 62-80. 
rev. hist. (São Paulo), n. 173, p. 211-251, jul.-dez., 2015 http://dx.doi.org/10.11606/issn.2316-9141.rh.2015.98800
Tiago Kramer de Oliveira

Roças, fazendas, engenhos, currais: uma cartografia da ruralidade colonial nas Minas do Cuiabá (primeira metade do século XVIII)

tempo vindouro uma fazenda de gado vacum e cavalar no sertão do Cuiabá na paragem chamada porto geral do Taquari". Seu objetivo seria produzir "mantimentos" uma vez que, de acordo com a carta, "os mineiros mais carecem deles por ser deserta e de evidentes riscos". Já em outra concessão, a narrativa aponta que Luiz Rodrigues,

agora assistente nestas minas do Cuiabá, que o suplicante com grande trabalho e despesas de sua fazenda povoara as terras de que estava de posse na barra de Camapuam Guasú caminho destas minas da parte que se segue grande utilidade aos mineiros, e viandantes que a elas passavam, por acharem naquela paragem mantimentos, e lhe ficar a viagem mais breve por um varadouro novo a que o dito suplicante tinha dado princípio, e porque no estabelecimento da dita fazenda tinha o suplicante feito uma considerável despesa e experimentado com a vizinhança do gentio bárbaro da nação Cayapó, grande perda pelos escravos que lhe havia mortos como era notório e porque do aumento da dita sua fazenda se seguia conveniência a fazenda real, e ao bem comum, e o suplicante se achava com posses de cultivar as ditas terras de baixo do mesmo risco, em que este agora se conservava se fabricar pelo campo vindouro uma fazenda de gado vacum e cavalar na mesma paragem ${ }^{28}$ (grifos nossos).

\section{FIGURA III}

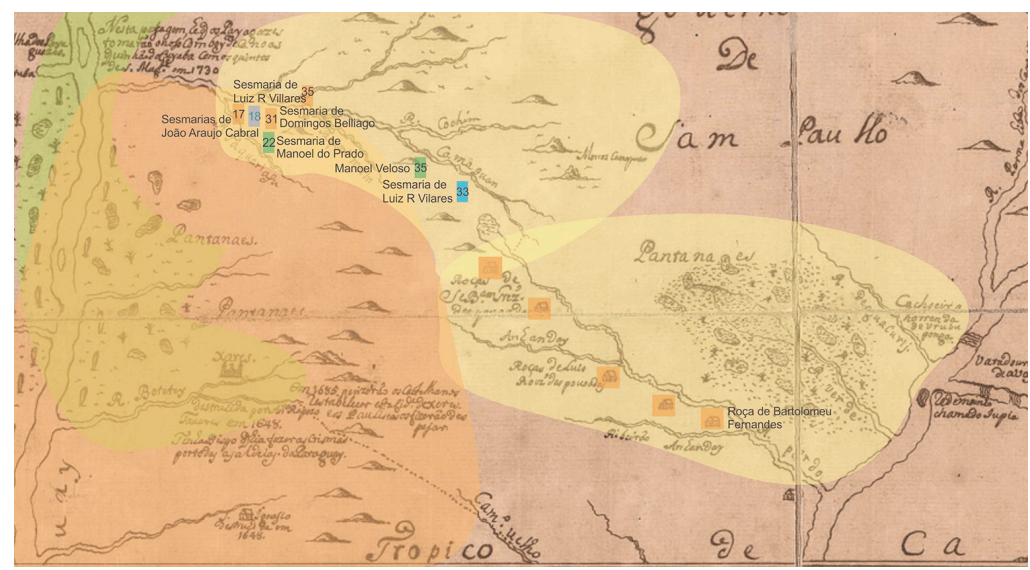

Detalhe do Parte do gouerno de Sam Paulo e parte dos dominios da Coroa de Espanha ca 1740, 51,5 x 71cm. Biblioteca Nacional (Brasil), Coleção Bibliotheca Nacional Publica da Corte. Indicamos a localização de terras com base em relatos e cartas de sesmarias, e as áreas aproximadas de ação de povos ameríndios, segundo os relatos, crônicas e correspondências. A numeração está de acordo com a ordem cronológica da concessão das cartas de sesmarias entre 1726 e 1728.

\footnotetext{
${ }^{28}$ Livro de sesmarias patentes e provisões. Livro 2. Apesp, f. 137-138.
} 
rev. hist. (São Paulo), n. 173, p. 211-251, jul.-dez., 2015 http://dx.doi.org/10.11606/issn.2316-9141.rh.2015.98800
Tiago Kramer de Oliveira

Roças, fazendas, engenhos, currais: uma cartografia da ruralidade colonial nas Minas do Cuiabá (primeira metade do século XVIII)

Pudemos averiguar que o dito Gregório de Castro apontado por Camelo é o mesmo que, na cidade de São Paulo, "constava como proprietário de loja e mercador. Todavia, sabe-se também que ele tinha negócios em Cuiabá, pois foi de lá que regressara com caixotes de ouro na monção de 1729". ${ }^{29}$ Borrego aponta ainda que o mesmo é citado em vários documentos "sempre envolvido com loja, fazendas e atividades em Cuiabá, Goiás e Rio de Janeiro". ${ }^{30}$

Outra carta concedida na região beneficiou a Manoel Veloso com uma légua e meia de terras em quadra. A concessão é justificada pelo fato de

ele suplicante se achava com posses de fabricar uma fazenda de gado vacum e cavalar com roças de mantimentos donde se utilize atenção aos mineiros que concorrem para estas minas de Cuiabá melhor passadio e maior aumento às rendas reais a qual dita fazenda quer o suplicante situar sobre o rio Camapuam correndo por ele abaixo da parte direita principiando donde faz barra o Camapuam Guassú confrontando com a terra de Luiz Rodrigues Villares ${ }^{31}$ (grifos nossos).

Não eram poucas as posses com as quais Manoel Veloso "se achava". Borrego estuda a trajetória de Manoel Veloso e cita documentação na qual o mesmo é mencionado como "homem de negócio dos mais honrados e bem procedidos desta cidade [São Paulo]".32 Seu inventário, de 1752, aponta um patrimônio líquido de 10:875:\$371.33 Manoel Veloso era sogro de Gregório de Castro, com quem "aparece muitas vezes como parceiro de negócios". ${ }^{4} \mathrm{O}$ nome de Luiz Rodrigues Villares aparece uma vez na tese de Borrego como marido de Ângela de Faria, filha de Manoel Veloso e, portanto, concunhado de Gregório. ${ }^{35}$

O que queremos problematizar não são os laços familiares entre homens de negócio, algo que a produção histórica mais recente destaca em muitas pesquisas, mas o sentido da formação de ambientes rurais nos territórios pertencentes ao termo da Vila do Cuiabá. É preciso que não percamos de vista que a acumulação de capital por agentes mercantis não implica somente em relações de reciprocidade baseadas em redes de clientes e parentes. Embora estudar essas relações seja fundamental para compreendermos o modus ope-

\footnotetext{
${ }_{29}^{29}$ BORREGO, Maria A. M. A teia mercantil: negócios e poderes em São Paulo colonial (1711-1765). Tese de doutorado em História, FFLCH, USP, 2006, p. 95.

30 BORREGO, Maria A. M., 2006, op. cit., p. 116.

${ }^{31}$ Livro de sesmarias patentes e provisões. Livro 2. Apesp, f. 142.

32 BORREGO, Maria A. M., 2006, op. cit., p. 116.

33 BORREGO, Maria A. M., 2006, op. cit., p. 208.

34 BORREGO, Maria A. M., 2006, op. cit., p. 256.

35 BORREGO, Maria A. M., 2006, op. cit., p. 262.
} 
rev. hist. (São Paulo), n. 173, p. 211-251, jul.-dez., 2015 http://dx.doi.org/10.11606/issn.2316-9141.rh.2015.98800
Tiago Kramer de Oliveira

Roças, fazendas, engenhos, currais: uma cartografia da ruralidade colonial nas Minas do Cuiabá (primeira metade do século XVIII)

randi da reprodução daquilo que João Fragoso chamou com muita propriedade de "hierarquia social excludente", ${ }^{6}$ é preciso ter em mente que as relações sociais, que permitem a estruturação das redes mercantis, espacializam-se. Apenas esse pequeno número de agentes sociais tomou posse de cerca de sessenta quilômetros quadrados de terras, onde possuíam volumosa escravatura, plantavam roças e ampliavam cada vez mais a criação de gado. Mas eles não eram os únicos a receber sesmarias entre o rio Camapuã e o Taquari.

Domingos Gomes Belliago, que também "fabricara um sítio nas margens do rio Taquari" onde possuía roças e criava gado, recebeu, em uma única carta de sesmarias, três léguas em quadra. ${ }^{37}$ A carta aponta que o requerente "se achava situado na mesma paragem com gado vacum, que conduzira de povoado em canoas com grande trabalho e despesa de sua fazenda", e ainda "mandara vir por serranias gado para meter na dita povoação". No relato de Barbosa de Sá para o ano de 1729, Domingos Gomes era um dos "homens mais ricos e de mais nome" da Vila Real. ${ }^{38}$

Domingos Gomes receberia mais três cartas de sesmarias nas Minas de Goiás, cerca de dez anos depois. Em 1739, então mestre de campo nas Minas de Goiás, recebeu três léguas de terra "em um sítio chamado Alagoa, em meio caminho da Meia-Ponte para o Tocantins que a houvera por título de compra (...) e tinha povoado com gados, escravos e roças"..$^{9}$

Outra carta aponta que Domingos Gomes, mestre de campo e "cavaleiro professo na ordem de Cristo", e os "reverendos José de Frias Vasconcelos e Antonio de Moraes Pimentel, eram senhores e possuidores de uma fazenda de gado, roça e engenho de cana nas cabeceiras do rio Paraná (...) por título de compra".40

E, por fim, uma carta em que o mesmo Domingos, juntamente com Antônio de Souza Bastos, recebe sesmaria de "umas fazendas", também nas Minas de Goiás, "onde acharam capacidade de mandarem povoar e, com efeito, tinham quatro fazendas já povoadas e levantando currais para povoarem

\footnotetext{
${ }^{36}$ FRAGOSO, João Luís Ribeiro. Homens de grossa aventura: acumulação e hierarquia na praça mercantil do Rio de Janeiro (1790-1830). Rio de Janeiro: Civilização Brasileira, 1998, p. 157. FLORENTINO, Manolo Ė FRAGOSO, João. O arcaísmo como projeto: mercado atlântico, sociedade agrária e elite mercantil em uma economia colonial tardia: Rio de Janeiro, c. 1790- c. 1840. Rio de Janeiro: Sette Letras, 1998, p. 12.

37 Livro de sesmarias patentes e provisões. Livro 2. Apesp, f. 133.

${ }^{38}$ SÁ, José Barbosa de. Relação das povoaçoens do Cuyabá e Mato Grosso de seos principios thé os presentes tempos. Annaes da Biblioteca Nacional, v. 23, 1901, p. 4-77, p. 25-26.

39 Livro de sesmarias patentes e provisões. Livro 9. Apesp, f. 37.

${ }^{40}$ Livro de sesmarias patentes e provisões. Livro 9. Apesp, f. 40.
} 
rev. hist. (São Paulo), n. 173, p. 211-251, jul.-dez., 2015 http://dx.doi.org/10.11606/issn.2316-9141.rh.2015.98800
Tiago Kramer de Oliveira

Roças, fazendas, engenhos, currais: uma cartografia da ruralidade colonial nas Minas do Cuiabá (primeira metade do século XVIII)

no tempo vindouro". Além das quatro fazendas "com bastante gados, cavalos e pessoas", os sócios requereram e obtiveram mais duas. ${ }^{41}$

João de Araújo Cabral, que viera de Itu, recebeu duas sesmarias no rio Taquari. ${ }^{42}$ Entre todos os que exploravam as terras na região, foi ele o primeiro a ter as suas legitimadas por carta de sesmarias, cerca de um ano antes dos demais, com a seguinte justificativa:

nesta minas do Cuiabá que sendo o suplicante um dos primeiros povoadores delas, para seu sustento, e da sua família fizera sítio e lançara roças na paragem chamada barra do Queixiyen [Coxim], que faz (...) descarregadouro de Taquari Guassû que tinha servido de grande utilidade aos passageiros para as ditas minas assim nas invernadas como se proverem de mantimentos cuja terra tinha princípio. ${ }^{43}$

Observando as narrativas sobre as viagens de São Paulo a Cuiabá, percebemos quão estratégica era a localização dessas terras. Os relatos de Cabral Camelo e Gervásio Rebelo e um relato anônimo com o título de Notícia $8^{a}$ prática $^{44}$ evidenciam a presença das roças de João de Araújo. ${ }^{45}$

A racionalidade que guiava os empreendimentos era orientada por uma lógica mercantil que visava os altos lucros que poderiam ser obtidos com a venda de "mantimentos" aos que percorriam o caminho que levava às Minas de Cuiabá. Uma relação dos preços das mercadorias nos dá uma perspectiva do lucro que tais roças realizavam.

\footnotetext{
${ }^{41}$ Livro de sesmarias patentes e provisões. Livro 9. Apesp, f. 41.

${ }^{42}$ Livro de sesmarias patentes e provisões. Livro 2. Apesp, f. 117; 118.

${ }^{43}$ Livro de sesmarias patentes e provisões. Livro 2. Apesp, f. 117.

${ }^{44}$ Segundo Thereza Martha B. Presotti, o roteiro é de 1726. PRESOTTI, Thereza Martha B. Os índios e a natureza na conquista colonial do centro da América do Sul: a capitania de Mato Grosso (século XVIII). In: CONGRESSO INTERNACIONAL ATLÂNTICO DE ANTIGO REGIME: PODERES E SOCIEDADES. Actas. Lisboa: Centro de História do Além-Mar - Cham/Faculdade de Ciências Humanas e Sociais/Universidade Nova de Lisboa, 2005, p. 1-24, p. 8.

${ }^{45}$ CAMELO, Antonio Cabral. Notícias práticas das minas do Cuiabá e Goyases na capitania de São Paulo e Cuiabá, que dá ao rev. padre Diogo Soares, o capitão João Antônio Cabral Camelo, sobre a viagem que fez às minas do Cuiabá no ano de 1727. RIHGB, v. 4, n. 13, 1842, p. 487-500, p. 492. REBELO, Gervásio Leite. Notícia $6^{\mathrm{a}}$ prática, e a relação verdadeira da derrota e viagem, que fez da cidade de São Paulo para as minas do Cuiabá o exmo. sr. Rodrigo César de Meneses governador e capitão-general da capitania de São Paulo e suas minas descobertas no tempo do seu governo, e nele mesmo estabelecidas (1727). In: TAUNAY, Affonso de E. História das Bandeiras paulistas. Relatos monçoeiros, tomo III. São Paulo, 1961, p. 111. Notícia $8^{a}$ prática. Exposta na cópia de uma carta escrita do Cuiabá aos novos pretendentes daquelas Minas. In: TAUNAY, Affonso de E. Relatos monçoeiros. Belo Horizonte: Itatiaia; São Paulo: Edusp, 1981, p. 188.
} 
rev. hist. (São Paulo), n. 173, p. 211-251, jul.-dez., 2015 http://dx.doi.org/10.11606/issn.2316-9141.rh.2015.98800
Tiago Kramer de Oliveira

Roças, fazendas, engenhos, currais: uma cartografia da ruralidade colonial nas Minas do Cuiabá (primeira metade do século XVIII)

TABELA I

\begin{tabular}{|l|c|c|c|}
\hline \multicolumn{4}{|c|}{ Preços registrados por Gervásio Leite Rebelo em 1726 } \\
\hline \multirow{2}{*}{ Gênero } & \multicolumn{3}{|c|}{ Preço em oitavas de ouro } \\
\cline { 2 - 4 } & Prox. do rio Pardo & Varadouro de Camapuã & Arraial do Sr. Bom Jesus do Cuiabá \\
\hline Milho (alqueire) & 12 & 9 & 14 \\
\hline Farinha de milho & - & - & 20 \\
\hline Feijão (alqueire) & 12 & 16 & 20 \\
\hline Galinha (unidade) & - & 3 & 3 \\
\hline Toucinho (arroba) & - & 32 & - \\
\hline Aguardente (frasco) & - & 15 & $11 / 2$ \\
\hline Ovos (dúzia) & - & - & - \\
\hline
\end{tabular}

Fonte: REBELO, Gervásio Leite. Notícia $6^{\mathrm{a}}$ prática, e a relação verdadeira da derrota e viagem, que

fez da cidade de São Paulo para as minas do Cuiabá o exmo. sr. Rodrigo César de Meneses governador e capitão-general da capitania de São Paulo e suas minas descobertas no tempo do seu governo, e nele mesmo estabelecidas (1727). In: TAUNAY, Affonso de E. História das Bandeiras paulistas.

Relatos monçoeiros, tomo III. São Paulo, 1961, p. 121-123.

Segundo Luna e Klein, um alqueire de milho ou de feijão equivalia, no século XVIII, a pouco mais de $30 \mathrm{~kg} .{ }^{46}$ Portanto, se pensarmos em uma unidade demedida atual, uma saca demilho de 60 kgcustaria,novaradouro deCamapuã, 18 oitavas de ouro. Uma vez que uma oitava correspondia a 1.500 réis, seriam 27.000 réis por saca. Portanto, cerca de quinze sacas de milho, ou trinta alqueires, era mais que suficiente para comprar um escravo acima do preço médio.

Se, por um lado, todas as cartas de sesmarias, assim como os relatos, apontam para a formação de unidades produtivas escravistas voltadas para o abastecimento, há também outro aspecto comum a todas essas cartas: a expansão das unidades produtivas e a diversificação da exploração. Além das roças, as cartas demonstram que havia o interesse em explorar a criação de gado em terras cada vez mais próximas da região conhecida como Campos da Vacaria, ao sul dos rios Taquari-açu, Taquari-mirim e Coxim. A segunda

\footnotetext{
${ }^{46}$ LUNA, Francisco Vidal \& KLEIN, Herbert S. Nota a respeito de medidas de grãos utilizadas no período colonial e as dificuldades para a conversão ao sistema métrico. Boletim de História Demográfica, v. 8, nº 21, 2001, p. 1-5, p. 4.
} 
rev. hist. (São Paulo), n. 173, p. 211-251, jul.-dez., 2015 http://dx.doi.org/10.11606/issn.2316-9141.rh.2015.98800
Tiago Kramer de Oliveira

Roças, fazendas, engenhos, currais: uma cartografia da ruralidade colonial nas Minas do Cuiabá (primeira metade do século XVIII)

carta de sesmaria passada a João de Araújo (três dias após a primeira) denota esse aspecto:

fizera sítio e lançara roças na paragem chamada barra Guexiyem, que faz (...) de sangradouro de Taquari Guassú, que tinha servido de grande conveniência (...) aos passageiros para as ditas minas assim nas invernadas que faziam naquela altura, como para se proverem de mantimentos (...) conveniente aos viandantes mas também a fazenda real e da outra parte do rio defronte do mesmo sítio do suplicante (...) feito e cultivado, se achavam campos devolutos com capacidade de criar gados, e o suplicante queria meter neles gados vacuns e formar fazenda (...) (grifos nossos). ${ }^{47}$

A utilização das cartas de sesmarias para a expansão de posses é recorrente na documentação. Como aponta Márcia Motta, "os que tinham assenhoreado enorme extensão de terras (...) se sentiam em crédito com a coroa. Não somente eles haviam cultivado ao menos parte daquelas terras, como se submeteram ao poder, ansiosos por receber a mercê que confirmaria seu direito a terra". ${ }^{48}$ A inserção de gado aproximava cada vez mais as fazendas dos territórios sob domínio Guaikuru (figura IV). Esta aproximação não provocou apenas conflitos, mas também relações de comércio, de gado e cavalos, entre os Guaykuru e os colonos. ${ }^{49}$

\footnotetext{
${ }^{47}$ Livro de sesmarias patentes e provisões. Livro 2. Apesp, f. 118.

${ }^{48}$ MOTTA, Márcia Maria M. Poder e domínio: a concessão de sesmarias em fins de Setecentos. In: MONTEIRO, Rodrigo B. \& VAINFAS, Ronaldo. Império de várias faces: relações de poder no mundo ibérico da Época Moderna. São Paulo: Alameda, 2009, p. 365.

${ }^{49}$ Especificamente sobre as relações dos conquistadores com os ameríndios Guaikuru, é importante destacar a tese de Uacury Bastos, na qual o autor define o território Guiakuru como fundamental para a compreensão das conquistas portuguesa e espanhola no "vale do Paraguai". BASTOS, Uacury Ribeiro Assis. Expansão territorial do Brasil colônia no vale do Paraguai (1767-1801). Tese de doutorado em História, FFLCH, USP, 1972. Mais recentemente, pesquisadores têm se dedicado de modo mais detido ao estudo das relações entre índios e conquistadores/colonos. Essas pesquisas, de uma forma geral, rompem com concepções unilaterais e maniqueístas a respeito dessas relações, evidenciando, de um lado, o aspecto estratégico da "incorporação" de ameríndios à sociedade colonial e, de outro, as estratégias indígenas nas alianças e conflitos com os "invasores". MEIRELES, Denise Maldi. Guardiães da fronteira: Rio Guaporé, século XVIII. Petrópolis: Vozes, 1989. MAGALHÃES, Magna Lima. Payaguá: os senhores do rio Paraguai. Dissertação de mestrado em História, Unisinos, 1999. ZAGO, Lisandra. Etnoistória Bororo: Contatos, alianças e conflitos (séculos XVIII e XIX). Dissertação de mestrado em História, UFMS, 2005. BLAU, Alessandra R. O ouro vermelho e a política de povoamento na capitania de Mato Grosso: 1752- 1798. Dissertação de mestrado em História, ICHS, UFMT, 2007. CARVALHO, Francismar A. L. de. Lealdades negociadas: povos indígenas e a expansão dos impérios ibéricos nas regiões centrais da América do Sul (segunda metade do século XVIII). Tese de doutorado em História, FFLCH, USP, 2012. Embora de extrema relevância, os estudos citados pouco exploram as primeiras décadas da colonização portuguesa no centro da América do Sul. Sem prejuízo às contribuições
} 
rev. hist. (São Paulo), n. 173, p. 211-251, jul.-dez., 2015 http://dx.doi.org/10.11606/issn.2316-9141.rh.2015.98800
Tiago Kramer de Oliveira

Roças, fazendas, engenhos, currais: uma cartografia da ruralidade colonial nas Minas do Cuiabá (primeira metade do século XVIII)

\section{FIGURA IV}

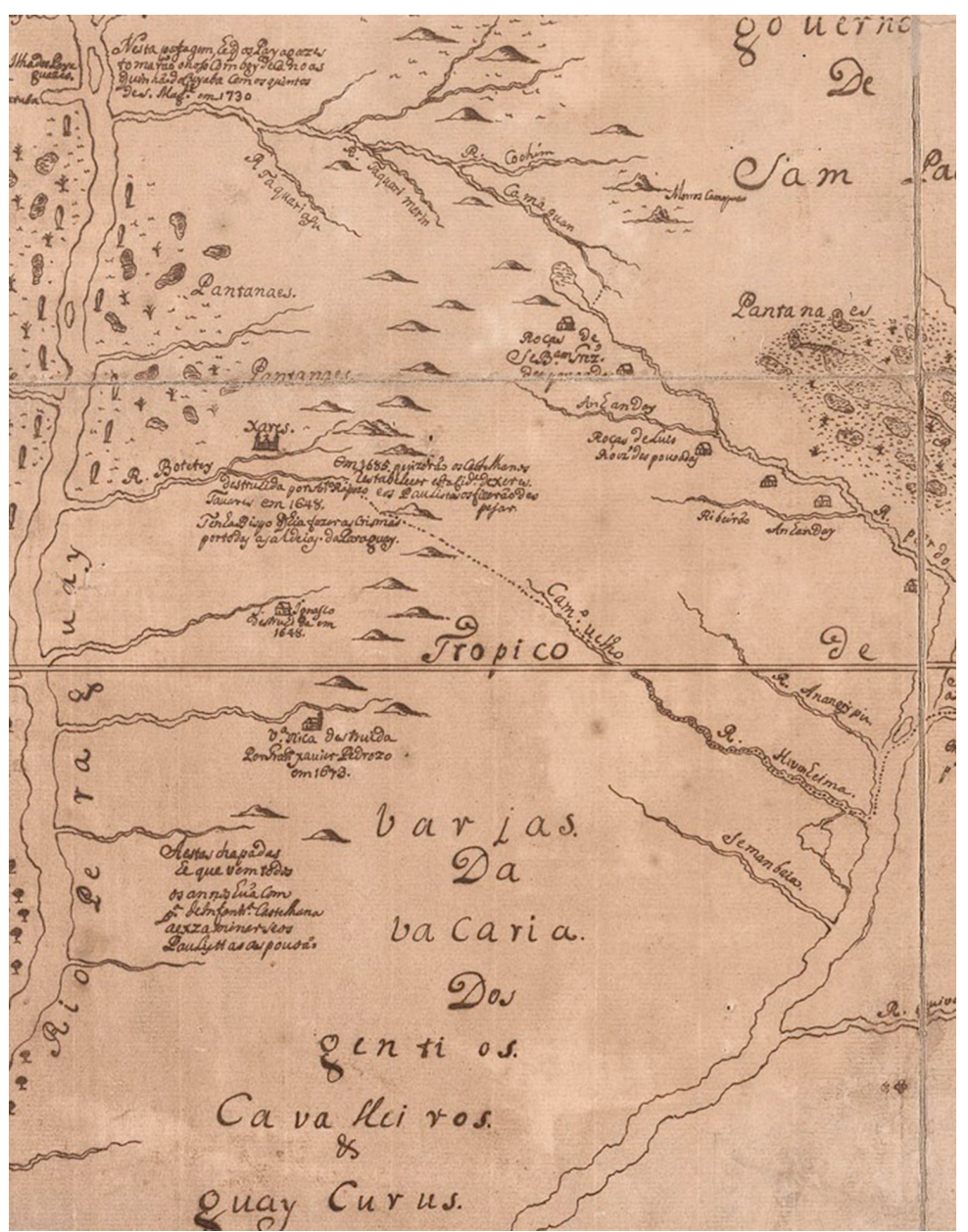

Detalhe de Parte do gouerno de Sam Paulo e parte dos dominios da Coroa de Espanha, ca $1740,51,5$ x $71 \mathrm{~cm}$. Biblioteca Nacional (Brasil), Coleção Bibliotheca Nacional Publica da Corte.

mais recentes, e tendo em vista a escala de análise e o objeto de estudo que nos propomos a discutir, a análise de John Manuel Monteiro, que destaca a escravização indígena como fundamento da expansão sertanista (embora sempre visasse à procura por metais preciosos), é mais adequada para tratarmos do avanço das conquistas portuguesas nos territórios ameríndios. MONTEIRO, John Manuel. Negros da Terra: índios e bandeirantes nas origens de São Paulo. São Paulo: Companhia das Letras, 1994. Contudo, os descobertos de ouro reorientariam as práticas sertanistas, articulando estas práticas à mineração, ao comércio e à produção agrária. OLIVEIRA, Tiago Kramer de. A paisagem do Pantanal e a ruralidade nas Minas do Cuiabá (primeira metade do século XVIII). Revista de História (USP), v. 164, 2011, p. 161-194, 165-169. 
rev. hist. (São Paulo), n. 173, p. 211-251, jul.-dez., 2015 http://dx.doi.org/10.11606/issn.2316-9141.rh.2015.98800
Tiago Kramer de Oliveira

Roças, fazendas, engenhos, currais: uma cartografia da ruralidade colonial nas Minas do Cuiabá (primeira metade do século XVIII)

Camelo aponta em seu relato que, em 1730, índios Guaykuru "se achavam (...) nas nossas rancharias, vendendo vacas, carneiros e alguns cavalos".50 Apenas em 1737, com o término da abertura do caminho por terra entre Cuiabá e Goiás, as Minas do Cuiabá teriam outra fonte mais segura e constante por onde introduzir gado, cavalos e muares nos ambientes rurais.

As relações que os Mbayá-Guaykurú mantiveram com os espanhóis, com os demais povos ameríndios e posteriormente com os portugueses revelam aspectos singulares da sociedade colonial engendrada no centro da América do Sul. Os Mbayá-Guaykurú, após a conquista da província dos Itatins, tornaram-se senhores de um vasto território no vale do Paraguai configurando-se em uma conquista ameríndia entre as conquistas ibéricas -, subjugando vários povos e aliando-se com outros.

Com o domínio absoluto sobre a região, os Guaykuru renomearam a geografia do país. Nas "terras mbaiânica", por exemplo, os rios Corrientes e Piray passaram a se chamar Apa e Aquidabam; o distrito que correspondia a Pitun, Piray Itati, passou a ser Agaguizo; o monte de San Fernando ganhou o nome de Itapucú-Guazú; o rio Guasarapo tornou-se Guache. ${ }^{51}$

A renomeação dos topônimos "evidencia a verdadeira supremacia destes índios sobre os territórios ocupados". Os Guaykuru tornaram-se ainda detentores de um imenso plantel de gado e de cavalos, fato que foi fundamental para que estes pudessem subjugar outros povos ameríndios e imporem-se aos conquistadores espanhóis e portugueses. Segundo Costa, "durante quase dois séculos estes índios foram senhores absolutos do território compreendido entre o Apa e o Mbotetey".52

Parece que, apesar da ênfase no discurso em relação à infâmia dos corsários Kayapó - que afugentariam além de portugueses outros povos ameríndios, os quais por gosto devorariam -, as terras entre os rios Pardo e Taquari foram conquistadas por vassalos do rei português. A desterritorialização de incontáveis povos ameríndios, justa para os sertanistas e para o poder real, fora certamente mais abrupta e traumática do que o jugo ao qual estes pode-

\footnotetext{
${ }^{50}$ CAMELO, Antonio Cabral. Notícias práticas das minas do Cuiabá e Goyases na capitania de São Paulo e Cuiabá, que dá ao rev. padre Diogo Soares, o capitão João Antônio Cabral Camelo, sobre a viagem que fez às minas do Cuiabá no ano de 1727. RIHGB, v. 4, n. 13, 1842, p. 487-500, p. 494.

${ }^{51}$ COSTA, Maria de Fátima. Notícias de Xarayes. Pantanal entre os séculos XVI e XVIII. Tese de doutorado em História, FFLCH, USP, 1997, p. 37.

${ }^{52}$ COSTA, Maria de Fátima, op. cit., 1997, p. 37-38.
} 
rev. hist. (São Paulo), n. 173, p. 211-251, jul.-dez., 2015 http://dx.doi.org/10.11606/issn.2316-9141.rh.2015.98800
Tiago Kramer de Oliveira

Roças, fazendas, engenhos, currais: uma cartografia da ruralidade colonial nas Minas do Cuiabá (primeira metade do século XVIII)

riam estar submetidos pelos infames Kayapó, os carniceiros Payagoá, e ainda os Guaikuru, que fariam "cruel guerra com outros gentios". ${ }^{3}$

O trecho já citado de Cabral Camelo, que aponta a existência no rio Taquari de "restos de algumas nações que os sertanistas conquistaram", é mais que indiciário das práticas de conquista. Por volta de dez anos após início da exploração sistemática das Minas do Cuiabá, o processo de conquista já havia desterritorializado e reterritorializado milhares de ameríndios, destruído aldeias inteiras, e territorializado ambientes coloniais. ${ }^{54}$

Depois da passagem ao rio Taquari, as demais menções são em relação aos Payagoá e Guaykuru, mas não se referem aos seus territórios e sim às relações conflituosas entre ameríndios e os colonos. A última referência feita por Camelo sobre essa presença foi no rio dos Porrudos (São Lourenço). Segundo Camelo, na barra do rio São Lourenço como na do rio Paraguai, "iam muitos Cuyabanos a salgar peixe para venderem"; no entanto, "dois ou três meses antes que eu chegasse deram os Payaguás em uma tropa de vinte e tantos, que estavam pescando na barra deste rio, e os mataram, escapando só dois ou três".55

Obviamente que havia ameríndios, e de inúmeros povos, entre a barra do rio Cuiabá e a vila que deste rio emprestou o nome; no entanto, na narrativa de Camelo, não mais havia lugar para os restos de nações. Já no relato de Antonio Pires de Campos, que teve como tema o "gentio bárbaro que há na derrota da viagem das Minas do Cuiabá", são citados vários povos. A maioria, no entanto, é mencionada após e anteriormente a verbos conjugados no passado: "habitavam", "viviam", "tinham", "usavam", "andavam". Não há, na narrativa de Pires de Campos sobre a presença de "gentios" entre a barra do Cuiabá e a Vila Real, nada violento ou conflituoso entre ameríndios e colonizadores.

Além dos relatos e correspondências, as cartas de concessão de sesmarias são documentos muito relevantes para o estudo da formação de ambientes rurais. Rodrigo César de Meneses concedeu, entre 1726 e 1728, 36 cartas de sesmarias a 38 requerentes.

Sobre essas cartas, Otávio Canavarros afirmou que, comparando-se os nomes dos beneficiados com "patentes de ordenanças e provisões de nome-

\footnotetext{
${ }^{5}$ CAMPOS, Antonio Pires de. Breve notícia que dá o capitão Antonio Pires de Campos. In: TAUNAY, Afonso de E. Relatos sertanistas. São Paulo: Livraria Martins Editora, 1976, p. 185.

${ }^{54}$ ROSA, Carlos Alberto. O urbano colonial na terra da conquista. In: ROSA, Carlos Alberto E JESUS, Nauk Maria de. A terra da conquista: história de Mato Grosso colonial. Cuiabá: Ed. Adriana, 2003, p. 23.

${ }^{55}$ CAMELO, Antonio Cabral. Notícias práticas das minas do Cuiabá e Goyases na capitania de São Paulo e Cuiabá, que dá ao rev. padre Diogo Soares, o capitão João Antônio Cabral Camelo, sobre a viagem que fez às minas do Cuiabá no ano de 1727. RIHGB, v. 4, n. 13, 1842, p. 487-500, p. 497.
} 
rev. hist. (São Paulo), n. 173, p. 211-251, jul.-dez., 2015 http://dx.doi.org/10.11606/issn.2316-9141.rh.2015.98800
Tiago Kramer de Oliveira

Roças, fazendas, engenhos, currais: uma cartografia da ruralidade colonial nas Minas do Cuiabá (primeira metade do século XVIII)

ações", constatou-se "uma certa reincidência de nomes". ${ }^{66}$ Sobre a localização, Canavarros aponta que "se procurava ocupar, basicamente, a baixada cuiabana e seu caminho fluvial (Capamuã, Taquari e Alto e Baixo Cuiabá), com uma extensão muito importante em direção à Chapada". ${ }^{57}$

Quanto à localização das terras concedidas por sesmaria, há muitos limites para uma aproximação. Na documentação, muitas vezes a referência à localização é apenas o fato de estar rio acima ou rio abaixo em relação à Vila do Cuiabá, ou na margem de um ou outro rio. São citados vizinhos que, por sua vez, não possuem cartas de sesmarias. São citadas cachoeiras e ribeirões sem topônimos e algumas vezes com topônimos difíceis de precisar (pela homonímia em relação a outros ou mesmo por não serem recorrentes na documentação). Todas essas dificuldades encerram a pretensão, de qualquer modo ilusória, de espelhar a formação de ambientes rurais. ${ }^{58}$ Outra questão importante é que mesmo que fosse possível localizar com alguma exatidão as cartas de sesmarias - o que seria realizável apenas com um árduo trabalho arqueológico - tal empresa apenas ofereceria indícios sobre a formação de ambientes rurais nesses primeiros tempos, pois não havia em relação a muitas terras a legitimação da posse por carta de sesmarias.

Representamos no croqui as cartas concedidas em territórios ao norte da barra do rio Cuiabá com o rio Paraguai. Das trinta e seis cartas, sete são concessões, como já vimos, de territórios que não estão circunscritos ao recorte espacial e estão localizadas no rio Taquari e em Camapuã.

Apesar das muitas ressalvas que fizemos, por meio do croqui é possível elaborar uma percepção da forma como as sesmarias estão dispostas em parte da região das Minas do Cuiabá.

As cartas de sesmarias da primeira metade do século XVIII não possuíam normatização quanto os dados a serem discriminados, mas algumas informa-

\footnotetext{
${ }^{56}$ CANAVARROS, Otávio. O poder metropolitano em Cuiabá (1727-1752). Cuiabá: EduFMT, 2004, p. 95.

${ }^{57}$ CANAVARROS, Otávio, op. cit., 2004, p. 95. Aspectos que foram reafirmados por Nauk Maria de Jesus: "a distribuição de sesmarias, entre o final do ano de 1726 e início de 1728, também fez parte da estratégia adotada pela Coroa portuguesa, que objetivava promover o assentamento da população e o desenvolvimento da produção local. (...). A reincidência de nomes na lista sugere a existência de um grupo especial de pessoas que faziam parte dos poderosos locais". JESUS, Nauk Maria de. Na trama dos conflitos: a administração na fronteira oeste da América portuguesa (1719-1778). Tese de doutorado em História, ICHF, UFF, p. 88.

${ }^{58}$ Sobre as pretensões da cartografia histórica em representar fielmente as espacializações das conquistas, ver: OLIVEIRA, Tiago Kramer de. Desconstruindo mapas, revelando espacializações: reflexões sobre o uso da cartografia em estudos sobre o Brasil colonial. Revista Brasileira de História, n. 68, 2014, p. 151-174.
} 
ções estão presentes em quase todas: a localização, a extensão, as atividades produtivas e o fato das terras serem ou não "devolutas", ou seja, inexploradas.

Primeiramente, podemos problematizar o caráter distributivo das concessões. No croqui da figura $V$, as figuras geométricas da cor laranja indicam terras nas quais os colonos já desenvolviam atividades produtivas. Das 36 sesmarias, 21 já estavam sendo exploradas, ao menos parcialmente. Das 14 restantes, 10 citam vizinhos que já exploram terras na localidade. Ou seja, ao menos 86\% são concessões de terras em locais onde já havia exploração de atividades rurais.

Quanto à localização das terras, algumas se situam nos caminhos que levam às Minas do Cuiabá, mas o maior número de concessões é referente às áreas situadas no rio Cuiabá, acima da Vila Real, no rio Coxipó-Açu e ainda na região da Chapada. Portanto, as terras onde há mais densidade de ocupação por ambientes rurais, de acordo com os relatos e correspondências - ou seja, entre a barra do rio Cuiabá e a Vila Real -, não estão onde há a maior quantidade de sesmarias.

Podemos perceber diferenças nas características das espacialidades rurais em relação a sua localização.

As sesmarias do rio Cuiabá abaixo são ao todo cinco. Nenhuma muito próxima ao ambiente urbano da vila. Uma foi requerida em 13 de janeiro de 1727 por Anselmo Gomes Ribeiro (8), ${ }^{59}$ que adquirira as terras por compra, mas argumentava não mais possuir o documento que comprovaria a venda e, por este motivo, requeria a sesmaria. ${ }^{60}$ Cita quatro vizinhos, entre eles três que não constam na documentação de sesmarias em tempo algum, e um outro, Antonio Borralho de Almeida.

\footnotetext{
${ }^{59}$ A numeração entre parêntese se refere à mesma numeração das cartas concedidas constantes do croqui da figura $\mathrm{V}$.

${ }^{60}$ Livro de sesmarias patentes e provisões. Livro 2. Apesp, f. 108-109.
} 


\section{FIGURA V}

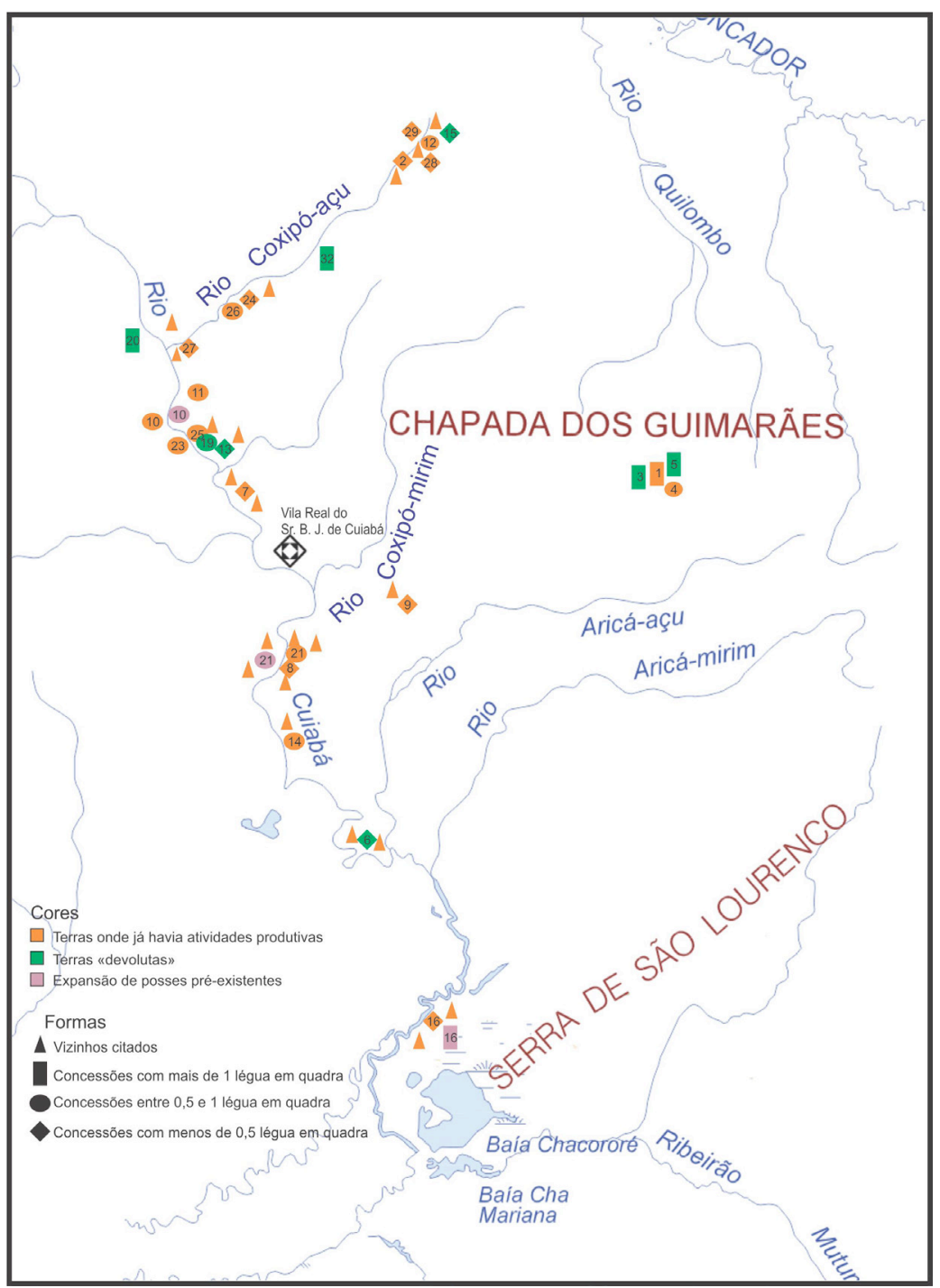

Croqui das sesmarias em Minas do Cuiabá - 1726-1728. Mapa base: IBGE. Mapa físico do Estado de Mato Grosso, 2010 (modificado, editado, adaptado).

O sobredito Antonio Borralho (21), não satisfeito com a demarcação das terras de Anselmo Gomes, não demoraria a protestar, alegando que formara "sítio, roças neste rio Cuiabá abaixo", além de ser "um dos primeiros moradores do rio Cuiabá abaixo", e aponta que "tinha mais uma beirada de matos, as quais cercavam suas roças que possuindo-as em boa fé não pedira delas 
sesmaria". ${ }^{61}$ Contudo, Borralho "tinha de presente notícia que Anselmo Gomes Ribeiro alcançara sesmaria da dita beira de terras sem prejuízo de terceiro, o suplicante se achava prejudicado por lhe pertencerem as ditas terras pelas razões alegadas". Na carta de concessão a Borralho lê-se: "que se havia feito a vistoria de uma e outra banda do dito rio, mandando recolher a carta de sesmaria passada a Anselmo Gomes Ribeiro para que em tempo nenhum pudesse prejudicar ao suplicante". A carta cita mais três vizinhos, entre eles dois que não foram denominados por Anselmo. Havia, portanto, ao menos sete propriedades vizinhas e muito provavelmente com limites incertos. ${ }^{62} \mathrm{E}$ muito provável que tanto Anselmo quanto Borralho tenham se utilizado de um expediente comum em requerimentos de sesmarias: tentar expandir ao máximo o limite de suas terras. ${ }^{63}$

O fato de Borralho apontar que as terras que estavam em litígio eram "beiradas de matos" que cercavam as roças mostra-nos um pouco sobre a paisagem rural e as práticas de exploração da terra. Certamente, essas seriam preferenciais àquelas que estavam completamente inexploradas. Ocupar terras onde já fora realizado o plantio e, posteriormente, que foram deixadas em descanso ou abandonadas poupava esforços dos colonos em abrir novas áreas. É com esse objetivo que outro requerente (6) pedira sesmarias no rio Cuiabá abaixo, entre dois sítios próximos ao Aricá, "aonde se achava o dito pedaço de mato devoluto que só tinha uma capoeira ${ }^{64}$ já deixada havia mais de um ano".65

Também entre dois sítios, outro requerente, Domingos Leme da Silva (16), que por sua vez "possuía um sítio nas margens do Cuiabá rio abaixo", alega que "se achava com gente bastante para fábrica do tal sítio e queria haver por carta de sesmaria para mais legitimamente o possuir". ${ }^{66}$ Domingos Leme declara que possuía um sítio que "de testada pelo rio mil e trezentas braças ou o que na verdade se achar", mas pede concessão de uma légua de terras em quadra e alega que "desta mercê se fazia digno o suplicante por ser um dos primeiros descobridores destas minas em cuja diligência expe-

\footnotetext{
${ }^{61}$ Livro de sesmarias patentes e provisões. Livro 2. Apesp, f. 120.

${ }^{62}$ Livro de sesmarias patentes e provisões. Livro 2. Apesp, f. 120.

${ }^{63}$ MOTTA, Márcia Maria M. Poder e domínio: a concessão de sesmarias em fins de Setecentos. In: MONTEIRO, Rodrigo B. E VAINFAS, Ronaldo. Império de várias faces: relações de poder no mundo ibérico da Época Moderna. São Paulo: Alameda, 2009, p. 352.

${ }^{64}$ Capoeira era como (e ainda é) denominada a vegetação formada em terras que já haviam sido exploradas em atividades agrícolas ou pastoris.

${ }^{65}$ Livro de sesmarias patentes e provisões. Livro 2. Apesp, f. 108.

${ }^{66}$ Livro de sesmarias patentes e provisões. Livro 2. Apesp, f. 117.
} 
rev. hist. (São Paulo), n. 173, p. 211-251, jul.-dez., 2015 http://dx.doi.org/10.11606/issn.2316-9141.rh.2015.98800
Tiago Kramer de Oliveira

Roças, fazendas, engenhos, currais: uma cartografia da ruralidade colonial nas Minas do Cuiabá (primeira metade do século XVIII)

rimentara consideráveis perdas". Mais uma vez, assim como Luiz Rodrigues Villares, Domingos Leme evoca os danos que experimentara na conquista dos territórios para legitimar seu requerimento e, de certa forma, impor ao poder real o reconhecimento por seus serviços. ${ }^{67}$ Mas o que nos interessa neste momento é chamar a atenção para o fato de que em todas as terras aqui citadas no rio Cuiabá abaixo, havia indícios de litígios, como no caso do requerimento de Miguel Antonio Sobral (14) que relata que as terras que pedia por sesmaria "tinha[m] povoado com roçado e casas e algumas plantas, e para evitar contendas a todo o tempo as queria por sesmarias, para seguramente continuar suas lavouras e por se achar com posse para as poder fabricar". ${ }^{68}$

Já as terras concedidas rio Cuiabá acima, ao noroeste da vila do Cuiabá, concentram-se nas margens do rio Cuiabá e do Coxipó-açu. Ao todo são 18 concessões, ou seja, quase 50\% do total. Também são citados, além dos requerentes, 10 outros vizinhos de 21 dos presentes em todas as cartas. A localização das 18 sesmarias, não por acaso, corresponde justamente aos locais de expansão recente de atividades sertanistas (exploração e mineração de ouro, aprisionamento de ameríndios e plantio de roças).

Nas últimas páginas de seu relato, Camelo aponta que havia, "fora da vila", três arraiais: Ribeirão, distante meia légua, Conceição, a uma légua, e Jacey, a três léguas, onde "em todos e nas suas vizinhanças se tem achado muitas e boas manchas de ouro, como também nas da vila; mas duraram pouco tempo, nestas se achavam folhetas e quase todo ouro era grosso". Já nas lavras do rio Coxipó-açú "que distam do Jacey três ou quatro léguas, assistem hoje alguns mineiros com lavras, e lhe chamam de Forfillas". Afirma ainda que "da outra parte do rio Cuiabá, em distância de nove ou dez léguas, há outras lavras, que chamam os Cocaes; e que são uns ribeirões ou córregos, que mostram algumas faisqueiras de ouro". Segundo Camelo, "adiante dos Cocaes dizem que ainda há algum gentio".69

\footnotetext{
${ }^{67}$ A questão da recompensa real pelos serviços prestados pelos agentes da colonização portuguesa é alvo de discussões entre os historiadores que estudam a administração colonial. Expomos o debate entre as diferentes interpretações e discutimos especificamente a ligação entre as relações de poder e a formação da ruralidade no centro da América do Sul. OLIVEIRA, Tiago Kramer de. Entre o oficial e o costumeiro: o exercício dos poderes e a espacialização da ruralidade no centro da América do Sul (primeira metade do século XVIII). Anais do Museu Paulista, v. 19, 2011, p. 129-157.

${ }^{68}$ Livro de sesmarias patentes e provisões. Livro 2. Apesp, f. 115.

${ }^{69}$ CAMELO, Antonio Cabral. Notícias práticas das minas do Cuiabá e Goyases na capitania de São Paulo e Cuiabá, que dá ao rev. padre Diogo Soares, o capitão João Antônio Cabral Ca-
} 
Emoutrodetalhedomapaanteriormentecitado(figuraVI),épossívelperceberindícios da expansão das lavras e da muito significativa presença ameríndia.

\section{FIGURA VI}

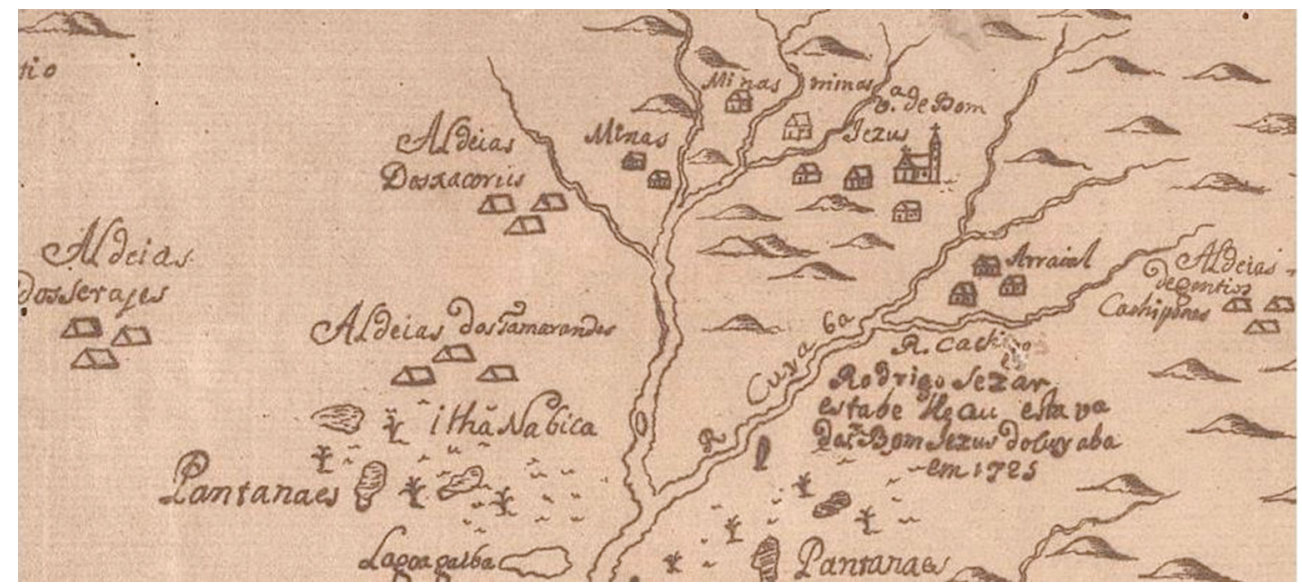

Detalhe de Parte do gouerno de Sam Paulo e parte dos dominios da Coroa de Espanha, ca 1740, 51,5 x 71cm. Biblioteca Nacional (Brasil), Coleção Bibliotheca Nacional Publica da Corte.

A forma como a rede fluvial está disposta (sem qualquer paralelo com a disposição dos rios em mapas atuais) dificulta a localização, mesmo que não muito aproximada. Mas podemos fazer mais que apontarmos "erros" na confecção do mapa. No detalhe da figura VI, percebemos que, além da Vila do Cuiabá, simbolizada por uma igreja com algumas casas defronte, há quatro outros núcleos populacionais representados por edificações. O primeiro, à direita da vila, assinalado apenas como "arraial", é provavelmente o arraial do Coxipó, nas margens do rio Coxipó-mirim. À esquerda da vila, estão outros três, apenas referenciados como "Minas", dos quais apenas o último é sinalizado por duas moradias, enquanto os outros dois apenas com uma.

Os indícios apontam que a expansão sistemática da exploração de ouro no rio Cuiabá acima se iniciou mais ou menos um ano antes da chegada de Rodrigo César de Meneses e se consolidou entre 1726 e 1728. O governador informa ao rei, em março de 1727, sobre um "novo descobrimento de ouro em

melo, sobre a viagem que fez às minas do Cuiabá no ano de 1727. RIHGB, v. 4, n. 13, 1842, p. 487-500, p. 501 (grifo nosso). 
distância de três dias destas minas, e afora mando examinar com vagar se tem conta que pelas boas disposições do terreno seguram os sertanistas mineiros (...) achando-se pedaços de outro de setecentas e quatrocentas oitavas".70

Em uma carta de sesmarias que concedia terras a Raimundo Leitão (25), ${ }^{71}$ o mesmo declarou ser "morador rio acima e primeiro povoador daquele sertão em cujas terras se situara no mês de junho do ano passado em cujo tempo não havia povoadores em distância de meio dia de viagem para rio abaixo", cujas terras tinham "bastante vizinhança de gentio bárbaro e sem embargo de tantos contratempos fizera o suplicante roça não só por utilidade sua mas também para aumentar a real fazenda como se mostrava dos dízimos". Assim como o capitão Francisco Pereira Gomes (24) ${ }^{72}$ que afirma ser "assistente nestas minas (e) por não ter terras capazes de cultivar para sustento da sua pessoa e escravos deu princípio ano passado a reduzir a cultura uns pedaços de mato no Coxipó Assú (...)" ${ }^{73}$ O reverendo José Barros Penteado $(12 ; 29)$ "dera princípio a cultivar terras da outra parte do dito rio da banda do sul, principiando a medição de uma árvore aonde ronha a medição de Francisco Vieira Barreto". ${ }^{74}$ Já Francisco Vieira Barreto (2) afirma ter feito roça "nas cabeceiras do Rio Coxipó Guassú" e "se achar no que está plantado possuindo pela parte de cima exmo. Padre José de Barros".75

Outros requerentes como José Paes Falcão $(15 ; 32),{ }^{76}$ que "se achava nas ditas minas com posses", procuraram terras para plantar roças nas cabeceiras do Coxipó. Na primeira carta concedida ao dito José Paes, em março de 1727, consta que "como no Coxipó Assu se achava uma sorte de terras que poderia ter mil braças que por toda a parte dividia a roça de Francisco Vieira Barreto e (...) estavam devolutas e as queria o suplicante". Em outra carta de concessão de terras ao já capitão José Paes Falcão e ao sargento mor Thomé de Lara Falcão, a narrativa que se desenrola distancia-se da formalidade do documento de sesmarias e aproxima-se do relato das práticas de conquista. Em fevereiro de 1728:

\footnotetext{
${ }^{70}$ Carta de Rodrigo César de Meneses ao rei d. João. Vila Real do Senhor Bom Jesus do Cuiabá, 12-03-1727. AHU-Mato Grosso, cx. 1, doc. 9.

${ }^{71}$ Livro de sesmarias patentes e provisões. Livro 2. Apesp, f. 124.

${ }^{72}$ Livro de sesmarias patentes e provisões. Livro 2. Apesp, f. 123.

73 Livro de sesmarias patentes e provisões. Livro 2. Apesp, f. 123.

${ }^{74}$ Livro de sesmarias patentes e provisões. Livro 2. Apesp, f. 128.

${ }^{75}$ Livro de sesmarias patentes e provisões. Livro 2. Apesp, f. 102-103.

${ }^{76}$ Livro de sesmarias patentes e provisões. Livro 2. Apesp, f. 116-135.
} 
rev. hist. (São Paulo), n. 173, p. 211-251, jul.-dez., 2015 http://dx.doi.org/10.11606/issn.2316-9141.rh.2015.98800
Tiago Kramer de Oliveira

Roças, fazendas, engenhos, currais: uma cartografia da ruralidade colonial nas Minas do Cuiabá (primeira metade do século XVIII)

(...) o sargento mor Thomé de Lara Falcão e o capitão José Paes Falcão, que eles tinham fábricas, e gente para botarem suas roças e por não terem terras próprias, mandaram por seus escravos e carijós buscar terras capazes para fazerem suas lavouras, as quais acharam junto ao morro, que está de fronte ao rio Coxipó, com capacidade e suficiência e nas quais começaram trabalhar de sorte, que hoje tinham plantado roça e nas ditas terras sem contradição de pessoa alguma e só agora se intrometiam o alferes Francisco da Rosa e (...) Jose Pinheiro a (...) perturbar aos suplicantes na pacífica posse que estavam somente com o pretexto de com licença dos administradores que os suplicantes mandaram com seus escravos para plantarem nas ditas terras algum mantimento para comerem enquanto estivessem naquela paragem fazendo bateias, como constava da justificação junta (...) e por evitarem semelhantes perturbações visto estarem de posse dos matos e estarem bastantes escravos, e carijós queriam possuir as ditas terras concedendo-lhes uma légua de terra em quadra por carta de data de terra de sesmaria, começando a medir a testada da paragem em que está a roça dos suplicantes correndo para o nascente (.... $)^{77}$

A prática de mandar escravos e índios administrados à procura de boas terras para as roças é recorrente em outras cartas, nos relatos e crônicas. É importante percebemos que a dinâmica da conquista das Minas do Cuiabá engendrava a formação de ambientes rurais fixos, os quais eram objeto inclusive de muitos litígios. Essas terras eram estratégicas para a exploração do ouro e para a expansão das atividades econômicas sertanistas. Obviamente que havia terras que eram abandonadas em função de esgotamento de algumas minas ou com a mudança de itinerários que poderiam tornar relativamente isoladas terras antes percorridas por colonos. Mas o que fica bastante claro nas cartas é que as terras tinham muito mais valor do que comumente se supõe.

Quando Camelo chegou a Cuiabá, em 1727, registrou que roças eram vendidas a "três ou quatro mil oitavas"! Os preços exorbitantes deveram-se, certamente, a alta demanda devido à vinda da comitiva do governador de São Paulo. Dois anos mais tarde, o preço era bem mais baixo, "cinquenta e cem". De todo o modo, evidencia-se que as terras não apenas adquiriram valor de uso, mas também valor de troca e constituíam-se em motivos de disputas.

As terras do rio Cuiabá acima e do rio Coxipó-açu concedidas por sesmarias eram exploradas e disputadas por homens que possuíam escravos, muitos índios administrados e posses. Das 18 cartas, em 15 foram declaradas posses de escravos para justificar a ocupação das terras. A quantidade de escravos poucas vezes é citada. Manoel da Silva Oliveira (13) declarou possuir "sete peças escravas".78 Lucas de Bairro Paiva (26) "se achava com mais

\footnotetext{
${ }_{77}$ Livro de sesmarias patentes e provisões. Livro 2. Apesp, f. 123.

${ }^{78}$ Livro de sesmarias patentes e provisões. Livro 2. Apesp, f. 114.
} 
rev. hist. (São Paulo), n. 173, p. 211-251, jul.-dez., 2015 http://dx.doi.org/10.11606/issn.2316-9141.rh.2015.98800
Tiago Kramer de Oliveira

Roças, fazendas, engenhos, currais: uma cartografia da ruralidade colonial nas Minas do Cuiabá (primeira metade do século XVIII)

de dez negros e camaradas". ${ }^{79}$ O padre José de Barros Penteado (29) pedira terras, segundo ele, para "se poder sustentar nelas e a vinte e cinco peças entre escravos e gentios de sua administração". ${ }^{80}$ Outros, porém, declararam apenas possuir escravos sem discriminar quantidade. Martinho Delgado de Camargo (19) requereu a posse de terras devolutas para nelas "se situar com bastantes escravos e famílias". ${ }^{81}$ Em outros casos, a presença de escravos é tácita, como na carta de Domingos Leme (16), que declara que "se achava com gente bastante para a fábrica do tal sítio". ${ }^{82}$ Além de seus próprios escravos, os "sertanistas mineiros" poderiam usar escravos de outros senhores. Pagava-se, em 1727, por "cada negro de jornal uma oitava", diminuiria nos anos seguintes. Segundo Camelo, "os negros bons dão doze vinténs, e meia oitava por dia, outros, meia pataca, alguns menos, e outros, nada". A presença de "camaradas" e "famílias" (que compreendia todos os membros submetidos ao patriarca, da sua esposa e filhos aos seus escravos) é recorrente na documentação, o que mostra que, além do trabalho compulsório, também homens livres formavam a população rural. ${ }^{84}$

Na primeira metade do século XVIII, a legislação não normatizara as informações que os requerentes deveriam prestar para receber sesmarias. Nas cartas desse período, elaboravam-se, como vimos, narrativas que justificavam e legitimavam a posse. Ser "primeiro morador", "povoador", ter "perdido gentes e fazendas" era mais que suficiente para fazê-lo, não sendo necessário enumerar outros enunciados, como "se achar com posses" etc. Mas, no caso dos requerentes recém-deslocados para as minas ou que procuravam reter-

\footnotetext{
${ }_{79}$ Livro de sesmarias patentes e provisões. Livro 2. Apesp, f. 125.

${ }^{80}$ Livro de sesmarias patentes e provisões. Livro 2. Apesp, f. 128.

${ }^{81}$ Livro de sesmarias patentes e provisões. Livro 2. Apesp, f. 119.

${ }^{82}$ Livro de sesmarias patentes e provisões. Livro 2. Apesp, f. 117.

${ }^{83}$ Carta de Rodrigo César de Meneses ao rei d. João. Vila Real do Senhor Bom Jesus do Cuiabá, 12-3-1727, AHU-Mato Grosso, cx. 1, doc. 9.

${ }^{84}$ Embora trate de Minas Gerais, uma capitania muito mais populosa, as afirmações de Angelo A. Carrara de que "no mínimo metade da população rural estabeleceu também desde o primeiro momento um padrão de produção rural que se adequa ao conceito de 'economia camponesa' e merece ser tomada como referência para uma aproximação". CARRARA, Angelo A. Minas e currais: produção rural e mercado em Minas Gerais 1674-1807. Juiz de Fora: Ed. UFJF, 2007, p. 65. No presente artigo, frisa-se que o quase silêncio sobre as espacializações camponesas deu-se em função da problemática que escolhemos e da documentação que abordamos. Sobre a significativa presença de livres pobres nos ambientes rurais e na formação da ruralidade nas Minas do Cuiabá desenvolvemos um estudo específico que ainda está por ser aprofundado. OLIVEIRA, Tiago Kramer de. Roceiros e camponeses no centro da América do Sul: a questão do campesinato em Mato Grosso no século XVIII. Revista do IHGMT, v. 68-69, 2011, p. 97-115.
} 
ritorializar suas práticas em espaços nos quais eram adventícios era comum a alusão a possuir "gente bastante", "escravos e carijós" etc.

A presença de escravos negros em grande parte das cartas mostra como, nas atividades sertanistas no centro da América do Sul, a utilização de "peças" africanas era fundamental para as engrenagens da empresa sertanista, não apenas para a exploração de ouro, mas também nos conflitos contra os ameríndios. O plantio de roças e a exploração aurífera eram atividades que se articulavam, conquistando espaço tanto em territórios ameríndios como também nas folhas da documentação de sesmarias. Outra prática igualmente importante era quase sempre silenciada nas cartas: o aprisionamento de ameríndios.

Estaria a atividade de aprisionamento e venda de índios arrefecendo-se com a consolidação da conquista? Os conflitos com ameríndios, pelo que podemos perceber, continuaram intensos. Nos últimos trechos do seu relato, o secretário do governador Rodrigo César, narra que "porque achando-se elas (estas Minas) cercadas de várias nações de gentio, que nos deixavam alargar pelo centro do sertão matando e sustentando-se de carne humana, procurou recon-

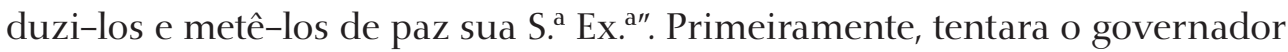
persuadi-los com "mimos de fumo, facas e outras semelhantes drogas, de não pouca estimação para eles: mas estes não só recusaram nossa amizade, mas responderam que eram homens, e que só à força de armas seriam mortos ou conquistados". Depois da "insolente resposta", Rodrigo César "mandou (...) por logo pronto um cabo com bastantes soldados sertanistas com ordem positiva, que os atacassem em qualquer parte, que os achassem: assim se fez e sem embargo de uma vigorosa resistência". O resultado: "mataram os nossos uma grande parte deles e trouxeram prisioneiro o resto com toda a sua família. Espera-se que os mais cabos, que S. ${ }^{a}$ Exc. ${ }^{a}$ mandou a diferentes partes consigam a mesma felicidade". ${ }^{85}$

Mais uma vez a alusão ao consumo de carne humana reforça a legitimidade da luta contra os ameríndios. Somada a isso, a "insolência" após a tentativa por parte do governador de fazer "amizade" com índios permitiu-lhe romper a fronteira entre as relações "pacíficas" e legitimar a morte e o aprisionamento. Outros prisioneiros e suas famílias certamente seriam também "trazidos" pelos cabos sertanistas. Mas, embora o discurso de Rebelo chegue ao fim com a palavra "felicidade", o desfecho para os sertanistas foi silenciado por Rebelo. Já o discurso do governador Rodrigo César de Meneses, que

\footnotetext{
${ }^{85}$ REBELO, Gervásio Leite , Notícia $6^{\mathrm{a}}$ prática... (1727), op. cit., p. 117.
} 
rev. hist. (São Paulo), n. 173, p. 211-251, jul.-dez., 2015 http://dx.doi.org/10.11606/issn.2316-9141.rh.2015.98800
Tiago Kramer de Oliveira

Roças, fazendas, engenhos, currais: uma cartografia da ruralidade colonial nas Minas do Cuiabá (primeira metade do século XVIII)

escreveu ao rei d. João V em 17 de março de 1727, é mais específico sobre o mesmo episódio. Apontou que, após a recusa dos "mimos" e o desafio que os ameríndios impuseram aos colonizadores, "fiz marchar o cabo que havia escolhido e lhe dei as ordens que havia executar o que fez atacando-os vigorosamente", e que os índios só desistiram ao "verem mortos quarenta e tantos dos seus, se renderam e foram trazidos a minha presença, que mandei repartir com igualdade, assim pelo cabo como pelos mais companheiros (...) ficando gentios administrados os dos brancos" e concluiu: "espero que as outras tropas (...) tenham o mesmo sucesso". Porém aos "administradores" não estava encerrado o ciclo. Barbosa de Sá afirma que partes do "povo", em 1727, "botaram-se para o sertão do gentio Bororo outros para os Parecis, que então se descobriram de onde traziam indivíduos de uma e outra nação que vendiam como escravos". ${ }^{86}$ Nota-se que não apenas os ameríndios considerados "bravios" eram aprisionados, mas também povos descritos como "mansos," como no caso dos Paresí. ${ }^{87}$

As sesmarias concedidas rio Cuiabá acima e Coxipó-açu provieram, portanto, da expansão das atividades sertanistas que passaram a articular cada vez mais o trabalho de livres e cativos indígenas ao trabalho dos escravos africanos e articular, também, as atividades agrárias e o poder edificado nos ambientes urbanos.

As demais sesmarias concedidas por Rodrigo César localizam-se na região da Chapada, atual Chapada dos Guimarães. Apenas quatro concessões. A primeira delas, e a primeira de todas as cartas concedidas nas Minas do Cuiabá, um ano antes da chegada do governador a Vila Real, foi ao então tenente-coronel Antonio de Almeida Lara (1). ${ }^{88}$ Na carta, a informação que "havia seis anos que o suplicante se achava situado e afazendado nas chapadas distante das minas tantos dois dias de jornada" e lá "fundou fazendas de roças canaviais e criações e se achava com mais de trinta escravos com (...) a dita fazenda que lhe tinha custado o cabedal naquele sertão a fabricá-la" e ainda "que tudo era em utilidade das mesmas Minas pelas estar socorrendo com

\footnotetext{
${ }^{86}$ SÁ, José Barbosa de. Relação das povoaçoens do Cuyabá e Mato Grosso de seos principios thé os presentes tempos. Annaes da Biblioteca Nacional, v. 23, 1901, p. 4-77, p. 21 (grifos nossos).

${ }^{87}$ Sobre os Paresí ver: CANOVA, Loiva. Os doces bárbaros: imagens dos índios Paresi no contexto da conquista portuguesa em Mato Grosso (1719-1757). Dissertação de mestrado em História, ICHS, UFMT, 2003. PRESSOTTI, Thereza Martha. Na trilha das águas: Índios e natureza na conquista colonial do centro da América do Sul, sertões e minas do Cuiabá e Mato Grosso, século XVIII (1718-1752). Tese de doutorado em História, UNB, 2008, p. 92-96; 225-231.

${ }^{88}$ Livro de sesmarias patentes e provisões. Livro 2. Apesp, f. 75-76.
} 
mantimentos e porque se acha sem títulos e para a conservação da dita fazenda e poder aumentá-la lhe era necessário uma légua de terra em quadra". ${ }^{9}$

As terras da Chapada converteram-se, portanto, desde 1721, em local para produção que abastecia o mercado das Minas do Cuiabá, particularmente em seu núcleo urbano principal. Outro potentado local que recebera sesmarias na Chapada foi o superintendente geral das minas, Antônio Álvares Lanhas Peixoto (5), ${ }^{90}$ além do secretário de governo de Rodrigo César de Meneses, Gervásio Leite Rebelo (3). ${ }^{91}$ Este último jamais exploraria efetivamente as terras. Além desses, Plácido de Moraes (4), ${ }^{92}$ que fora o único a receber terras na Chapada com menos de uma légua em quadra. Certamente havia outros que exploravam essas áreas da Chapada como se pode supor na declaração de que lá "se achavam alguns moradores situados". 93

Dividimos, portanto, as sesmarias concedidas por Rodrigo César em quatro grupos. O primeiro compreende a região entre Camapuã e Taquari, com roças e fazendas que fundamentalmente abasteciam os "viandantes" e onde se dava início, em meados da década de 1720, à expansão da criação de gado nas terras vizinhas aos domínios dos Guaykuru. Um segundo, nas terras entre as margens do rio Cuiabá abaixo (em relação à Vila Real), onde se plantavam roças que abasteciam os viajantes, os moradores da vila e onde se expandiam, a partir de 1727, os engenhos de cana. Um terceiro, de posses exploradas no contexto da expansão das atividades sertanistas no rio Cuiabá acima e no Coxipó-açu que, em grande parte, subsidiavam a exploração de ouro e o aprisionamento de ameríndios. E, finalmente, um quarto, na Chapada, voltado basicamente para o abastecimento do mercado local, cujo principal núcleo era a Vila Real do Senhor Bom Jesus do Cuiabá, mas onde se realizavam práticas de exploração cuja expansão exigia ampliação do mercado consumidor. Apesar da diferenciação, relativamente arbitrária, todas essas espacialidades rurais estavam articuladas entre si, inclusive com homens que circulavam por elas como proprietários, exploradores ou autoridades régias.

Reconstruímos algumas características da formação da ruralidade nas Minas do Cuiabá, o que tornou possível uma percepção diversa daquela cristalizada pelas interpretações consagradas sobre as conquistas portugue-

\footnotetext{
${ }^{89}$ Livro de sesmarias patentes e provisões. Livro 2. Apesp, f. 75-76.

${ }^{90}$ Livro de sesmarias patentes e provisões. Livro 2. Apesp, f. 105.

${ }^{91}$ Livro de sesmarias patentes e provisões. Livro 2. Apesp, f. 102-103.

${ }^{92}$ Livro de sesmarias patentes e provisões. Livro 2. Apesp, f. 104.

${ }^{93}$ Registro de uma patente de brigadeiro destas Minas de Antonio de Almeida Lara, 30-12-1726. Livro de sesmarias patentes e provisões. Livro 2. Apesp.
} 
rev. hist. (São Paulo), n. 173, p. 211-251, jul.-dez., 2015 http://dx.doi.org/10.11606/issn.2316-9141.rh.2015.98800
Tiago Kramer de Oliveira

Roças, fazendas, engenhos, currais: uma cartografia da ruralidade colonial nas Minas do Cuiabá (primeira metade do século XVIII)

sas no centro da América do Sul. Embora de forma incipiente e não definitiva, houve considerável especialização regional da produção agrária: de áreas voltadas para o plantio de mantimentos para os "viandantes" (nos caminhos fluviais e terrestres); terras para o plantio de cana-de-açúcar e edificação de engenhos (na Chapada dos Guimarães); terras para produção de mantimentos e para expansão das atividades sertanistas (a oeste da Vila do Cuiabá); e áreas destinadas à criação de gado (na parte norte do Pantanal mato-grossense).

Expomos elementos que insinuam articulações entre a espacialização desses ambientes às dinâmicas políticas e econômicas mais amplas, que escapam do recorte espacial restrito que estabelecemos neste texto. O estudo do texto convida à revisão do contexto.

Uma análise atenta dos resultados que apresentamos possibilita aproximá-los das referências bibliográficas sumariamente apresentadas no começo do artigo. Reafirmamos que a formação de ambientes rurais ocorreu em concomitância aos descobrimentos auríferos. Encontramos evidências de que a produção de alimentos utilizou trabalho escravo em escala considerável para os padrões demográficos locais. Contudo, há elementos que ultrapassam o limite das interpretações citadas, pois a perspectiva que nossa análise insinua confronta-se com a ideia da produção rural como atividade "acessória", constituída para dar sustentação à exploração do ouro, ou um setor endógeno que inicia e termina seu ciclo no interior das fronteiras coloniais. ${ }^{94}$ Percebemos que a exploração da terra estava articulada aos interesses

\footnotetext{
${ }^{94}$ Fazemos óbvia alusão ao modo como duas principais vertentes explicativas têm servido aos historiadores para "enquadrar" as práticas econômicas não diretamente ligadas às atividades exportadoras. De um lado, aqueles que, ancorados em Caio Prado Júnior e Fernando Novais, destacam o caráter secundário e acessório dessas práticas produtivas, que serviam de sustentação àquelas "fundamentais" que caracterizavam a colonização. Em outro lado, os autores que se alinham às pesquisas de Ciro Flamarion Cardoso e, particularmente, aos trabalhos de João Fragoso e Manolo Florentino para defender o caráter endógeno dessas atividades que, em seu conjunto, dão sustentação a uma hierarquia social excludente que tem no topo uma elite colonial sediada no Rio de Janeiro. PRADO JÚNIOR, Caio. Formação do Brasil contemporâneo - Colônia. São Paulo: Brasiliense, 1997. NOVAIS, Fernando A. Portugal e Brasil na crise do antigo sistema colonial (1777-1808). São Paulo: Hucitec, 1986. FLORENTINO, Manolo \& FRAGOSO, João. $O$ arcaísmo como projeto: mercado atlântico, sociedade agrária e elite mercantil em uma economia colonial tardia: Rio de Janeiro, c. 1790- c. 1840. Rio de Janeiro: Sette Letras, 1998. Deixamos a ressalva de que esta alusão merece uma análise mais aprofundada pelo menos por três motivos: trabalhos muito significativos foram produzidos à luz dessas abordagens; as obras dos autores merecem uma leitura mais aprofundada do que aquela que tem sido feita por seus críticos (e mesmo por seus seguidores); e as abordagens oferecem fecundos caminhos para novas pesquisas que não necessariamente precisam alinhar-se a uma delas.
} 
rev. hist. (São Paulo), n. 173, p. 211-251, jul.-dez., 2015 http://dx.doi.org/10.11606/issn.2316-9141.rh.2015.98800
Tiago Kramer de Oliveira

Roças, fazendas, engenhos, currais: uma cartografia da ruralidade colonial nas Minas do Cuiabá (primeira metade do século XVIII)

mercantis por meio de relações de comércio e pela consequente imbricação da economia local às redes mercantis mais amplas. Pudemos seguir os rastros de Manuel Veloso, Luiz Rodrigues Villares e Gregório de Castro, e identificamos como seus interesses mercantis relacionavam-se com a espacialização de ambientes rurais em Curitiba, Cuiabá e Goiás. Mas suas trajetórias pessoais os ligavam a dinâmicas econômicas que extrapolavam sua rede de interesses e de parentesco. Ao identificamos a significativa presença de escravos africanos nos ambientes rurais voltados para a produção agrícola, e a crescente demanda por armas, pólvora e ferramentas, nos perguntamos sobre as articulações dessas espacialidades com a dinâmica do mercado atlântico.95

Em que pese a imensa contribuição das interpretações de Linhares e Teixeira da Silva, parece que, para avançarmos nas trilhas deixadas por esses autores, alguns aspectos de sua interpretação devem ser problematizados, em particular a noção de que a produção de alimentos era um dos três pilares que sustentavam a grande lavoura. Nossa hipótese, ainda por ser testada com mais rigor, é que, no período estudado, a primeira metade do século XVIII, o tráfico internacional de escravos e os interesses dos grupos mercantis ligavam-se tão estreitamente à produção de alimentos e produtos consumidos internamente quanto à produção de ouro e cana-de-açúcar para o mercado externo. Trata-se de um momento específico da economia colonial,

\footnotetext{
${ }^{95}$ As pesquisas sobre o tráfico de escravos e sua relação com a dinâmica do comércio atlântico têm revelado aspectos sobre as relações entre os domínios ultramarinos portugueses e a economia europeia e africana que merecem ter suas implicações avaliadas pelos estudos em história econômica do Brasil colonial. Destacamos as pesquisas de Joseph Miller sobre as relações econômicas, sociais e políticas que em Brasil, Angola e Portugal permitiram e impulsionaram o tráfico. MILLER, Joseph C. Capitalism and slavery: the financial and commercial organization of the Angolan slave trade, according to the accounts of Antonio Coelho Guerreiro (1684-1692). International Journal of African Historical Studies, v. 17, n. 1, 1984, p. 1-15. MILLER, Joseph. Way of death: Merchant capitalism and the Angolan slave trade 1730-1830. Madison: University of Wisconsin Press, 1988. O quadro exposto pela equipe coordenada por David Eltis, que aponta o crescimento do desembarque de escravos durante o período de arrefecimento da exploração de ouro, merece ser explicado à luz da dinâmica da economia colonial. ELTIS, David; BEHRENDT, Sthephen D.; RICHARDSON, David. A participação dos países da Europa e das Américas no tráfico transatlântico de escravos: novas evidências. Afro-Ásia, n² 24, 2000, p. 09-50, p. 49. Salutar é a problematização de Miller sobre a necessidade de compreender as especificidades temporais do Atlântico escravista. MILLER, Joseph C. O Atlântico escravista: açúcar, escravos, engenhos. Afro-Ásia, n 19; 20, 1997, p. 9-36. Atentos às questões abertas por essas abordagens, Maximiliano Menz e Gustavo Acioli discutiram a diversidade temporal e espacial do tráfico de escravos para o Brasil, na Angola e na Costa da Mina, durante o século XVIII. ACIOLI, Gustavo $\mathcal{E}$ MENZ, Maximiliano M. Resgate de mercadorias: uma análise comparada do tráfico luso-brasileiro de escravos em Angola e na Costa da Mina (século XVIII). Afro-Ásia, 37, 2008, p. 43-73.
} 
rev. hist. (São Paulo), n. 173, p. 211-251, jul.-dez., 2015 http://dx.doi.org/10.11606/issn.2316-9141.rh.2015.98800
Tiago Kramer de Oliveira

Roças, fazendas, engenhos, currais: uma cartografia da ruralidade colonial nas Minas do Cuiabá (primeira metade do século XVIII)

com a emergência de um amplo setor mercantil de migrantes portugueses que se instala em Rio de Janeiro, ${ }^{96}$ Pernambuco, ${ }^{97}$ Bahia, ${ }^{98}$ São Paulo ${ }^{99}$ e irradia-se para os interiores da América, possibilitando o surgimento de um grupo de comerciantes em Cuiabá. ${ }^{100}$ São redes mercantis que espacializam seus negócios desde os portos africanos até as roças nas mais recentes conquistas.

No que diz respeito às relações de poder e às práticas administrativas, não temos espaço para uma profunda discussão. Faremos alguns apontamentos. Percebemos, até pela localização das terras, que a concessão de sesmarias serviu para legitimar a posse em casos de litígio e como modo de articular a conquista da terra (já em curso) à malha escriturária da administração portuguesa. A urdidura entre a dinâmica das relações econômicas e os interesses dos diversos agentes sociais e políticos não pode ser desvelada minimizando a importância das espacializações em favor da análise de relações de poder circunscritas ao âmbito local ou a uma rede de interesses particulares. Há uma tendência na historiografia brasileira em superdimensionar as redes clientelares, nas quais os valores e comportamentos são bastante próprios das elites do Antigo Regime europeu, em detrimento da análise das relações de exploração do trabalho e da terra que espacializavam ambientes urbanos e rurais bastante diversos dos do velho continente e que evidenciam o caráter colonial das conquistas portuguesas na América. ${ }^{101}$

${ }^{96}$ SAMPAIO, Antonio C. Na encruzilhada do Império: hierarquias sociais e conjunturas econômicas no Rio de Janeiro (c. 1650-c. 1750). Rio de Janeiro: Arquivo Nacional, 2001, p. 39.

${ }^{97}$ MELLO, Evaldo Cabral de. A fronda dos mazombos, nobres contra mascates: Pernambuco 1666-1715. São Paulo: Cia das Letras, 1995, p. 123-187.

${ }^{98}$ FLORY, Rae Jean Dell $\mathcal{E}$ SMITH, David Grant. Bahian merchants and the planters in the seventeenth and early eighteenth centuries. Hispanic American Historical Review, no 58, v. 4, 1978, p. 571-594, p. 575. RIBEIRO, Alexandre Vieira. O comércio de escravos e a elite baiana no período colonial. In: FRAGOSO, João L. R.; ALMEIDA, Carla Maria C. de; SAMPAIO, Antonio Carlos Jucá de. Conquistadores e negociantes: histórias de elites no Antigo Regime nos trópicos. Rio de Janeiro: Civilização Brasileira, 2007, p. 329.

${ }^{99}$ BORREGO, Maria A. M. A teia mercantil: negócios e poderes em São Paulo colonial (1711-1765). Tese de doutorado em História, FFLCH. USP, 2006, p. 37.

${ }^{100}$ ROSA, Carlos Alberto. O comércio da conquista. Revista Universidade, ano II, $\mathrm{n}^{\circ} 1$. Cuiabá: UFMT, 1982, p. 35; ROSA, Carlos Alberto. O urbano colonial na terra da conquista. In: ROSA, Carlos Alberto $\mathcal{E}$ JESUS, Nauk Maria de. A terra da conquista: história de Mato Grosso colonial. Cuiabá: Ed. Adriana, 2003, p. 24.

${ }^{101}$ Como enfaticamente apontou Laura de Mello e Souza em suas críticas aos autores que negligenciaram as relações escravistas e o caráter colonial das conquistas como mediadoras das relações de poder na América portuguesa do século XVIII. SOUZA, Laura de Mello e. O sol e a sombra: política e administração na América portuguesa do século XVIII. São Paulo: Cia das Letras, 2006, p. 69. 
rev. hist. (São Paulo), n. 173, p. 211-251, jul.-dez., 2015 http://dx.doi.org/10.11606/issn.2316-9141.rh.2015.98800
Tiago Kramer de Oliveira

Roças, fazendas, engenhos, currais: uma cartografia da ruralidade colonial nas Minas do Cuiabá (primeira metade do século XVIII)

Por outro lado, seria igualmente minimizador superdimensionar o poder da Coroa portuguesa. As concessões de sesmarias não expressaram um mecanismo unilateral da Coroa, não foram resultado de um "plano" de fomentar a produção agrícola ou o povoamento por meio de doação de terras inexploradas. Obviamente que havia interesses da administração, em uma capitania de mineração de fronteira, em garantir o abastecimento e consolidar espacializações. ${ }^{102}$ Reduzir, contudo, a formação desses ambientes rurais ao resultado de uma "política colonial" significa empobrecer sobremaneira a riqueza dos indícios documentais e ignorar, por exemplo, as práticas costumeiras de conquista do espaço. ${ }^{103}$

O que o estudo das concessões de sesmarias nos permite problematizar, portanto, é como os interesses pessoais de autoridades, os interesses geopolíticos portugueses e os interesses mercantis articulavam-se de diversas maneiras à formação de ambientes rurais. ${ }^{104}$ Relações que em nível macro apresentam-se de forma nebulosa. Apenas estudos que as explorem em escala reduzida podem revelar os meandros das práticas sociais que permitem,

\footnotetext{
${ }^{102}$ A especificidade da capitania de Mato Grosso como de mineração e de fronteira, caso, aliás, único na América portuguesa, levou autores a exagerar o caráter determinante dessas características. Luíza Volpato, por exemplo - ao explorar a documentação que descrevia Mato Grosso como antemural das conquistas portuguesas -, e Otávio Canavarros - ao constatar que, a partir da década de 1730, os interesses geopolíticos do "poder metropolitano" pareciam suplantar as expectativas com a exploração de ouro - tenderam a reduzir essas espacializações aos planos da geografia política portuguesa. VOLPATO, Luiza Rios Ricci. A conquista da terra no universo da pobreza: formação da fronteira oeste do Brasil. São Paulo: Hucitec, 1987, p. 46; CANAVARROS, Otávio. O poder metropolitano em Cuiabá (1727-1748). Cuiabá: Ed. da UFMT, 2004, p. 57. Uma contribuição interessante, no sentido oposto e complementar às análises acima citadas, foi desenvolvida por Carlos Rosa em um curto artigo que revela como a edificação de engenhos (proibida por lei) assumiu um caráter geopolítico nas relações de poder por meio de alianças de interesses entre os senhores de engenho, as autoridades reinóis e a geografia política portuguesa que objetivava conservar as conquistas em Cuiabá e em Mato Grosso. ROSA, Carlos Alberto. Canas, escaroçadores, alambiques, aguardentes: sinais da produção local do Cuiabá na Relação de Barbosa de Sá. Revista do IHGMT, v. 58, 2000.

${ }^{105}$ Discussão pormenorizada em OLIVEIRA, Tiago Kramer de. Entre o oficial e o costumeiro: o exercício dos poderes e a espacialização da ruralidade no centro da América do Sul (primeira metade do século XVIII). Anais do Museu Paulista, v. 19, 2011, p. 129-157.

${ }^{104}$ Além dos estudos de Márcia Motta, já citados, um bom exemplo da exploração dessas relações para a primeira metade do século XVIII é o estudo de Rafael Chambouleyron e Vanice Siqueira de Melo. CHAMBOULEYRON, Rafael \& MELO, Vanice Siqueira de. Governadores, índios, guerras e terras entre o Maranhão e o Piauí (primeira metade do século XVIII). Revista de História (São Paulo), n. 168, 2013, p. 167-200.
} 
ao mesmo tempo, a consolidação de poderes locais e o exercício de práticas centralizadoras por parte do poder régio. ${ }^{105}$

Temos a expectativa de que nosso estudo seja um contributo ao trabalho, levado a cabo por vários pesquisadores, de redesenhar o mapa da história agrária do Brasil colonial e ainda para problematizar as técnicas e métodos empregados pelos mapmakers de Clio na construção de conhecimento histórico sobre a expansão das conquistas portuguesas na primeira metade do século XVIII. Caso nossos leitores julguem tal expectativa como desmedidamente ambiciosa, estamos satisfeitos em oferecer um mapa em menor escala que detalhe as práticas espacializadas na formação dos ambientes rurais, nos primeiros anos das conquistas portuguesas no centro da América do Sul.

\section{Referências bibliográficas}

ACIOLI, Gustavo \& MENZ, Maximiliano M. Resgate de mercadorias: uma análise comparada do tráfico luso-brasileiro de escravos em Angola e na Costa da Mina (século XVIII). Afro-Ásia, 37, 2008, p. 43-73.

ANZAI, Leny Caselli. Doenças e práticas de cura na capitania de Mato Grosso: o olhar de Alexandre Rodrigues Ferreira. Tese de doutorado em História, UNB, 2004.

ARRUDA, Elmar Figueiredo. O mercado interno de Mato Grosso - século XVIII. Dissertação de mestrado em História, PUC, 1987.

BASTOS, Uacury Ribeiro Assis. Expansão territorial do Brasil colônia no vale do Paraguai (1767-1801). Tese de doutorado em História, FFLCH, USP, 1972.

BETHENCOURT, Francisco. Political configurations and local powers. In: BETHENCOURT, Francisco \& CURTO, Diogo Ramada (org.). Portuguese oceanic expansion, 1400-1800. Nova York: Cambridge University Press, 2007.

BLAU, Alessandra R. O ouro vermelho e a política de povoamento na capitania de Mato Grosso: 1752- 1798. Dissertação de mestrado em História, ICHS, UFMT, 2007.

BORREGO, Maria A. M. A teia mercantil: negócios e poderes em São Paulo colonial (17111765). Tese de doutorado em História, FFLCH, USP, 2006.

CANAVARROS, Otávio. O poder metropolitano em Cuiabá (1727-1748). Cuiabá: Ed. da UFMT, 2004.

CANOVA, Loiva. Os doces bárbaros: imagens dos índios Paresi no contexto da conquista portuguesa em Mato Grosso (1719-1757). Dissertação de mestrado em História, ICHS, UFMT, 2003.

\footnotetext{
${ }^{105}$ BETHENCOURT, Francisco. Political configurations and local powers. In: BETHENCOURT, Francisco \& CURTO, Diogo Ramada (org.). Portuguese oceanic expansion, 1400-1800. Nova York: Cambridge University Press, 2007, p 197-254, p. 200.
} 
rev. hist. (São Paulo), n. 173, p. 211-251, jul.-dez., 2015 http://dx.doi.org/10.11606/issn.2316-9141.rh.2015.98800
Tiago Kramer de Oliveira

Roças, fazendas, engenhos, currais: uma cartografia da ruralidade colonial nas Minas do Cuiabá (primeira metade do século XVIII)

CARDOSO, Ciro Flamarion S. A brecha camponesa no sistema escravista. In: CARDOSO, Ciro Flamarion S. Agricultura, escravidão e capitalismo. Petrópolis: Vozes, 1979.

. As concepções acerca do "sistema econômico mundial" e do "antigo sistema colonial": a preocupação obsessiva com a "extração de excedente". In: AMARAL LAPA, J. R. do (org.). Modos de produção e realidade brasileira. Petrópolis: Vozes, 1980.

CARRARA, Angelo Alves. Ocupação territorial e estrutura fundiária: as minas e os currais (1674-1850). Estudos de História, Franca, v. 08, n. 2, 2001, p. 81-97.

Minas e currais: produção rural e mercado em Minas Gerais 1674-1807. Juiz de Fora: Ed. UFJF, 2007.

CARVALHO, Francismar A. L. de. Lealdades negociadas: povos indígenas e a expansão dos impérios ibéricos nas regiões centrais da América do Sul (segunda metade do século XVIII). Tese de doutorado em História, FFLCH, USP, 2012.

CHAMBOULEYRON, Rafael \& MELO, Vanice Siqueira de. Governadores, índios, guerras e terras entre o Maranhão e o Piauí (primeira metade do século XVIII). Revista de História (São Paulo), n. 168, 2013, p. 167-200.

CORRÊA FILHO, Virgílio. Pantanais matogrossenses. Devassamento e ocupação. Rio de Janeiro: IBGE, 1946.

CORTESÃO, Jaime. História do Brasil nos velhos mapas, tomo II. Lisboa: Imprensa Nacional; Casa da Moeda, 2009.

COSTA, Maria de Fátima. Notícias de Xarayes. Pantanal entre os séculos XVI e XVIII. Tese de doutorado em História, FFLCH, USP, 1997.

DELEUZE, Gille \& GUATTARI, Félix. Mil platôs - capitalismo e esquizofrenia, v. 1. Tradução de Ana Lúcia de Oliveira. Rio de Janeiro: Ed. 34, 1995.

ELTIS, David; BEHRENDT, Sthephen D.; RICHARDSON, David. A participação dos países da Europa e das Américas no tráfico transatlântico de escravos: novas evidências. Afro-Ásia, n² 24, 2000, p. 09-50.

FLORENTINO, Manolo E FRAGOSO, João. O arcaísmo como projeto: mercado atlântico, sociedade agrária e elite mercantil em uma economia colonial tardia: Rio de Janeiro, c. 1790 - c. 1840. Rio de Janeiro: Sette Letras, 1998.

FLORY, Rae Jean Dell \& SMITH, David Grant. Bahian merchants and the planters in the seventeenth and early eighteenth centuries. Hispanic American Historical Review, n 58, v. 4, 1978, p. 571-594.

FRAGOSO, João Luís Ribeiro. Homens de grossa aventura: acumulação e hierarquia na praça mercantil do Rio de Janeiro (1790-1830). Rio de Janeiro: Civilização Brasileira, 1998.

FURTADO, Celso. Formação econômica do Brasil. 32ª edição. São Paulo: Companhia Editora Nacional, 2003.

GOMES, Masília A. da S. Os "gêneros do país": a produção de alimentos em Vila Bela da Santíssima Trindade (1748-1790). In: ANZAI, Leny C. \& MARTINS, Maria Cristina B. Histórias coloniais em áreas de fronteira: índios, jesuítas e colonos. São Leopoldo, RS: Oikos; Unisinos; Cuiabá, MT: EduFMT, 2008.

GUIMARÃES, Carlos Magno $\mathcal{E}$ REIS, Liana M. Agricultura e escravidão em Minas Gerais (1700/1750). Revista do Departamento de História da UFMG, 1986. 
rev. hist. (São Paulo), n. 173, p. 211-251, jul.-dez., 2015 http://dx.doi.org/10.11606/issn.2316-9141.rh.2015.98800
Tiago Kramer de Oliveira

Roças, fazendas, engenhos, currais: uma cartografia da ruralidade colonial nas Minas do Cuiabá (primeira metade do século XVIII)

HAESBAERT, Rogério \& BRUCE, Glauco. A desterritorialização em Deleuze e Guattari. GEOgraphia, ano 6, nº 7, 2002, p. 07-31.

HAESBAERT, Rogério $\&$ RAMOS, Tatiana T. O mito da desterritorialização econômica. GEOgraphia, ano 6, n 12, 2004, p. 25-48, p. 29; 45-46.

HAESBAERT, Rogério. $O$ mito da desterritorialização: do "fim dos territórios" à multiterritorialidade. Rio de Janeiro: Bertrand Brasil, 2006.

HOLANDA, Sérgio Buarque. Caminhos e fronteiras. São Paulo: Cia das Letras, 1994.

JESUS, Nauk Maria de. Na trama dos conflitos: a administração na fronteira oeste da América portuguesa (1719-1778). Tese de doutorado em História, ICHF, UFF, 2006.

LINHARES, Maria Y. Subsistência e sistemas agrários na colônia, uma discussão. Estudos Econômicos, USP, vol. 13, número especial, 1983.

Pecuária, alimentos e sistemas agrários no Brasil (séculos XVII e XVIII). Tempo, v. 1, n. 2, 1996, p. 132-150.

LINHARES, Maria Yedda $\mathcal{E}$ TEIXEIRA DA SILVA, Francisco Carlos. História da agricultura brasileira, combates e controvérsias. São Paulo: Brasiliense, 1981.

LUNA, Francisco Vidal $\mathcal{E}$ KLEIN, Herbert S. Nota a respeito de medidas de grãos utilizadas no período colonial e as dificuldades para a conversão ao sistema métrico. Boletim de História Demográfica, v. 8, 2001, nº 21.

MAGALHÃES, Magna Lima. Payaguá: os senhores do rio Paraguai. Dissertação de mestrado em História, Unisinos, 1999.

MEIRELES, Denise Maldi. Guardiães da fronteira: Rio Guaporé, século XVIII. Petrópolis: Vozes, 1989.

MELLO, Evaldo Cabral de. A fronda dos mazombos, nobres contra mascates: Pernambuco 1666-1715. São Paulo: Cia das Letras, 1995.

MENESES, José Newton Coelho. O continente rústico: abastecimento alimentar nas Minas Gerais setecentistas. Diamantina: Maria Fumaça, 2000.

MILLER, Joseph C. Capitalism and slavery: the financial and commercial organization of the Angolan slave trade, according to the accounts of Antonio Coelho Guerreiro (1684-1692). International Journal of African Historical Studies, v. 17, n. 1, 1984, p. 1-15. 1997, p. 9-36.

O Atlântico escravista: açúcar, escravos, engenhos. Afro-Ásia, nº 19; 20,

. Way of death: Merchant capitalism and the Angolan slave trade 1730-1830. Madison: University of Wisconsin Press, 1988.

MONTEIRO, John Manuel. Negros da Terra: índios e bandeirantes nas origens de São Paulo. São Paulo: Companhia das Letras, 1994.

MOTTA, Marcia M. Menendes. Direito à terra no Brasil: a gestação do conflito, 1795-1824. São Paulo: Alameda, 2009.

Francisco Maurício de Souza Coutinho: sesmarias e os limites do poder. In: VAINFAS, Ronaldo; SANTOS, Georgina Silva dos; NEVES, Guilherme Pereira (org.). Retratos do Império: trajetórias individuais no mundo português nos séculos XVI ao XIX. Niterói: EdUFF, 2006.

Nas fronteiras do poder: conflito de terra e direito à terra no Brasil do século XIX. Rio de Janeiro: Vício de Leitura; Aperj, 1998. 
rev. hist. (São Paulo), n. 173, p. 211-251, jul.-dez., 2015 http://dx.doi.org/10.11606/issn.2316-9141.rh.2015.98800
Tiago Kramer de Oliveira

Roças, fazendas, engenhos, currais: uma cartografia da ruralidade colonial nas Minas do Cuiabá (primeira metade do século XVIII)

Poder e domínio: a concessão de sesmarias em fins de Setecentos. In: MONTEIRO, Rodrigo B. \& VAINFAS, Ronaldo. Império de várias faces: relações de poder no mundo ibérico da Época Moderna. São Paulo: Alameda, 2009.

NOVAIS, Fernando A. Portugal e Brasil na crise do antigo sistema colonial (1777-1808). São Paulo: Hucitec, 1986.

OLIVEIRA, Tiago Kramer de. A paisagem do Pantanal e a ruralidade nas minas do Cuiabá (primeira metade do século XVIII). Revista de História (USP), v. 164, 2011, p. 161-194.

. Cartografias do "sertão": os mapas sertanistas nos discursos históricos de Jaime Cortesão e Sérgio Buarque de Holanda. Territórios E Fronteiras, v. 6, n. 2, 2013, p. 188-210.

Desconstruindo mapas, revelando espacializações: reflexões sobre o uso da cartografia em estudos sobre o Brasil colonial. Revista Brasileira de História, n. 68,2014, p. 151-174.

Roceiros e camponeses no centro da América do Sul: a questão do campesinato em Mato Grosso no século XVIII. Revista do IHGMT, v. 68-69, 2011, p. 97-115.

Entre o oficial e o costumeiro: o exercício dos poderes e a espacialização da ruralidade no centro da América do Sul (primeira metade do século XVIII). Anais do Museu Paulista, v. 19, 2011, p. 129-157.

Ruralidade na terra da conquista: Ambientes rurais luso-americanos no centro da América do Sul (1716-1750). Dissertação de mestrado, UFMT, 2008.

PEDREIRA, Jorge Miguel de M. V. Os homens de negócio da praça de Lisboa de Pombal ao Vintismo (1755-1822): diferenciação, reprodução e identificação de um grupo social. Tese de doutorado, Universidade Nova de Lisboa, 1995.

PRADO JÚNIOR, Caio. Formação do Brasil contemporâneo - Colônia. São Paulo: Brasiliense, 1997.

PRESOTTI, Thereza Martha B. Os índios e a natureza na conquista colonial do centro da América do Sul: a capitania de Mato Grosso (século XVIII). In: CONGRESSO INTERNACIONAL ATLÂNTICO DE ANTIGO REGIME: PODERES E SOCIEDADES. Actas. Lisboa: Centro de História do Além-Mar - Cham/ Faculdade de Ciências Humanas e Sociais/Universidade Nova de Lisboa, 2005.

. Na trilha das águas: Índios e natureza na conquista colonial do centro da América do Sul, sertões e minas do Cuiabá e Mato Grosso, século XVIII (1718-1752). Tese de doutorado em História, UNB, 2008.

REVEL, Jacques. Microanálise e a construção do social. In: REVEL, Jacques. Jogos de escalas: a experiência da microanálise. Tradução de Dora Rocha. Rio de Janeiro: EFGV, 1998.

RIBEIRO, Alexandre Vieira. O comércio de escravos e a elite baiana no período colonial. In: FRAGOSO, João L. R.; ALMEIDA, Carla Maria C. de; SAMPAIO, Antonio Carlos Jucá de. Conquistadores e negociantes: histórias de elites no Antigo Regime nos trópicos. Rio de Janeiro: Civilização Brasileira, 2007.

ROSA, Carlos Alberto \& JESUS, Nauk Maria de. A terra da conquista: história de Mato Grosso colonial. Cuiabá: Ed. Adriana, 2003. 
rev. hist. (São Paulo), n. 173, p. 211-251, jul.-dez., 2015 http://dx.doi.org/10.11606/issn.2316-9141.rh.2015.98800
Tiago Kramer de Oliveira

Roças, fazendas, engenhos, currais: uma cartografia da ruralidade colonial nas Minas do Cuiabá (primeira metade do século XVIII)

A Vila Real do Senhor Bom Jesus do Cuiabá. Vida urbana em Mato Grosso no século XVIII (1727-1808). Tese de doutorado em História, FFLCH, USP, 1996.

Canas, escaroçadores, alambiques, aguardentes: sinais da produção local do Cuiabá na Relação de Barbosa de Sá. Revista do IHGMT, v. 58, 2000.

UFMT, 1982.

O comércio da conquista. Revista Universidade, ano II, $\mathrm{n}^{\circ}$ 1. Cuiabá:

SAMPAIO, Antonio C. Na encruzilhada do Império: hierarquias sociais e conjunturas econômicas no Rio de Janeiro (c. 1650 - c.1750). Rio de Janeiro: Arquivo Nacional, 2001.

SANTOS, Milton. A natureza do espaço: técnica, razão e emoção. São Paulo: Edusp, 2006. . Metamorfoses do espaço habitado: fundamentos teórico e metodológico da geografia. São Paulo: Hucitec, 1988.

SENA, Divino Marcos de. Camaradas: livres e pobres em Mato Grosso (1808-1850). Dissertação de mestrado em História, UFGD, 2010.

SILVA, Jovam Vilela da. Mistura de cores. Política de povoamento e população na capitania de Mato Grosso - século XVIII. Cuiabá: UFTM, 1995.

SILVA, Vanda da. Administração das terras: a concessão de sesmarias na capitania de Mato Grosso (1748-1823). Dissertação de mestrado em História, ICHS, UFMT, 2008.

SODRE, Nelson Werneck. Oeste. Ensaio sobre a grande propriedade pastoril. São Paulo: Arquivo do Estado, 1990.

SOUZA, Laura de Mello e. O sol e a sombra: política e administração na América portuguesa do século XVIII. São Paulo: Cia das Letras, 2006.

TEIXEIRA DA SILVA, Francisco Carlos. Pecuária e formação do mercado interno no Brasil-colônia. Estudos Sociedade e Agricultura, 1997, p. 119-156.

VOLPATO, Luiza Rios Ricci. A conquista da terra no universo da pobreza: formação da fronteira oeste do Brasil. São Paulo: Hucitec, 1987.

ZAGO, Lisandra. Etnoistória Bororo: Contatos, alianças e conflitos (séculos XVIII e XIX). Dissertação de mestrado em História, UFMS, 2005.

ZEMELLA, Mafalda P. O abastecimento da capitania das Minas Gerais no século XVIII. São Paulo: Ed. Hucitec-Edusp, 1990. 
